\title{
Preserving the Exceptional Republic: Political Economy, Race, and the Federalization of American Immigration Law
}

\author{
Matthew J. Lindsay*
}

In February 1885, United States Senator John Ingalls urged his colleagues during floor debate "to consider whether it may not be patriotic and prudent ... to modify existing views as to the Declaration of Independence and the universal rights of man." "[U]nless measures are taken to protect the American people, to protect this great civilization," he continued, "within a brief space dangers as great as those that have overthrown monarchs and despots may with ruthless rage assail the institutions of republican freedom." ${ }^{2}$ The menace of which Ingalls warned was not an imminent invasion by foreign armies, but rather the immigration to the United States of hordes of "foreign pauper laborers." Congressman Martin Foran sounded a similar theme several months earlier when he introduced the legislation championed by himself and Ingalls-the Contract Labor Act of 1885-to the House of Representatives. It was pure folly, Foran admonished, to believe "that our advanced and vigorous race [cannot be] deteriorated by coming in contact with other races or people." 3 Unless Congress took swift action, he predicted, the United States would soon be left with "no energy, no American manhood, no moral convictions, no republic."4 Such dire

* Visiting Scholar, American Academy of Arts and Sciences. M.A. History, University of Chicago, 1995; J.D. Yale Law School, 2002; Ph.D. History (expected, 2006) University of Chicago. For their valuable insights, I am grateful to the exceptionally thoughtful and attentive editors at the Yale Journal of Law and Humanities, to David Fontana, William Forbath, Christian Ford, Robert Gordon, Jonathan Hansen, Dan Sharfstein, Reva Siegel, Amy Dru Stanley, and especially to Kim Reilly. Portions of this Article have been completed with the generous support of the American Academy of Arts and Sciences.

1. 16 CONG. REC. 1624 (1885).

2. $I d$.

3. 16 CONG. REC. 5351 (1884).

4. Id. 
exhortations must have struck a chord, for the Contract Labor Act passed both houses of Congress by an overwhelming majority. The Act prohibited the admission into the United States of European immigrants who set sail from their homelands after having entered into a labor contract with an American employer.

Even as its sponsors insisted that the Act was essential to the preservation of American political values and institutions, both proponents and opponents of the legislation, within Congress and without, acknowledged that it contradicted two cardinal tenets of the nation's republican faith-first, the United States' historic liberality toward immigrants, rooted in Americans' confidence in the power of an open continent and free institutions to assimilate all comers; and second, the Gilded-Age understanding of the wage contract as the hallmark of economic freedom and personal independence. Yet Congress countenanced these apparent contradictions because, it concluded, a great number of European immigrants were irredeemably unfit-economically, politically, and, most significantly, racially-for inclusion within the American polity. This Article explains why patriotic republicans across the political spectrum joined in this "modification" of the nation's founding principles, and how a class of immigrants that less than a generation earlier had been widely celebrated as the lifeblood of the nation came to be viewed as a menace to American institutions.

The Contract Labor Act was one of a spate of federal immigration laws enacted between 1882 and 1891, through which the federal government assumed virtually exclusive control over a regulatory sphere that historically had been the province of the states. ${ }^{5}$ This Article argues that the new federal immigration regime was created through Congress' attempt to reconcile the nation's most cherished ideological commitment - the notion that the United States would forever remain an exceptional, "free labor" republic - with the unprecedented social and economic convulsions of the 1870 s and 1880 s. Since before the nation's founding, the core of the free labor ideal was the belief that a man's capacity for virtuous republican citizenship necessarily depended on his

5. Foremost among the federal interventions were the Immigration Act of 1882 , ch. 376,22 Stat. 214 (1882), transferring authority to oversee the landing of immigrants from individual states to the United States Treasury Department, see infra text accompanying notes 126-130; the Chinese Exclusion Act of 1882, ch. 126, 22 Stat. 58 (1882), prohibiting the entry of Chinese laborers into the United States for a period of ten years; the Contract Labor Act of 1885, chs. 161-64, 23 Stat. 332 (1885), prohibiting any person or company "to prepay the transportation, or in any way assist or encourage the importation or migration of . . . any foreigner ... to perform labor or service of any kind in the United States," see infra text accompanying notes 143-161; and the Immigration Act of 1891, ch. 551, 26 Stat. 1084 (1891), reaffirming key provisions of the 1882 and 1885 Acts, transferring the sole authority to administer immigration regulations to the federal government, and creating the office of the Superintendent of Immigration, under the authority of the Secretary of the Treasury, see infra text accompanying notes 234-241. 
attainment of a kind of personal "freedom" that could only be secured through economic "independence." Originally, true independence, and thus political virtue, was firmly rooted in the ownership of both real property and the means of one's economic livelihood. Under this model, men who labored for wages were considered economically and personally dependent on their employers, and thus incapable of virtuous citizenship. ${ }^{6}$ This "early republican" version of the free labor ideal suffered a series of shocks over the course of the century, as the industrial reorganization of labor made the traditional material prerequisites for independence unavailable to an increasingly large proportion of the adult male population. As historians have demonstrated, Americans responded not by abandoning the free labor ideal, but by redefining the conditions of independence to suit the new industrial era. By the postbellum period, when the industrial revolution was in full swing and wage earning had become the norm rather than the exception, male industrial hirelings could claim the economic freedom and independence required for virtuous republican citizenship through the simple act of consenting to sell their labor for a wage. ${ }^{7}$ Here was a political economy for the era of wage labor, and the ideological crucible in which Americans forged a new federal immigration regime.

As this Article demonstrates, the meaning of both immigrants and immigration was fundamentally transformed when two successive, though distinct, crises of mass economic dependency disturbed this reconstructed free labor worldview. The first was the wrenching depression that began in 1873 and lasted throughout the decade. ${ }^{8}$ The United States experienced for the first time in its history the phenomenon of sustained unemployment, widespread public begging, and the chronic dependency of entire families. Americans confronted the spectacle of throngs of adult, able-bodied men whose subsistence outside of formal employment

6. See William E. Forbath, The Ambiguities of Free Labor: Labor and Law in the Gilded Age, 1985 Wis. L. Rev. 767, 774. See also LawrenCE B. Glickman, A Living Wage: AMerican WORKERS AND THE MAKING OF CONSUMER CULTURE 22-24 (1997); DAVID MONTGOMERY, BEYOND EQUALITY: LABOR AND THE RADICAL REPUBLICANS, 1862-1872, at 30-33 (1981); DAVID R. ROEDIGER, THE WAGES OF WHITENESS: RACE AND THE MAKING OF THE AMERICAN WORKING CLASS 65-87 (1992); DANIEL ROGERS, THE WORK ETHIC IN INDUSTRIAL AMERICA, 1850-1920, at 30-64 (1974); Amy Dru Stanley, From Bondage to Contract: Wage Labor, MarRiage, and tHe Market In the Age of SLAve EManCipation 9-10 (1998); Robert J. STEINFELD, THE INVENTION of Free Labor: THe EMployment Relation in ENGlish and american Law and CUlture, 1350-1870, at 185-87 (1991).

7. GLICKMAN, supra note 6, at 17-34; ROGERS, supra note 6, passim; STANLEY, supra note 6, at $1-59$.

8. The worldwide depression of the 1870 s was the worst economic downturn of the nation's history. For public officials, charity administrators, and many other observers, the masses of unemployed adult, able-bodied, male heads-of-household begging in the streets for the support of their families signaled not only an economic crisis; it portended a profound and much more far-reaching threat to the nation's social and political order. See infra notes 75-77 and accompanying text. 
relations failed to satisfy even the stripped down, industrial-era conception of economic independence through wage labor. In the early $1880 \mathrm{~s}$, this first crisis of dependency was superceded by a second, as a chorus of observers charged that the starvation wages for which "American" workers were compelled to labor degraded them as men and as citizens. This second crisis of dependency struck at the heart of the free labor ideal even more forcefully than the first, implying that the wage contract itself might be an inadequate vehicle for independence and freedom. In both cases, however, the conspicuous social consequences of an industrial labor system premised on liberal economic relations seemed increasingly at odds with the republican values of manly independence and citizenly virtue.

This Article argues that the federal regime of immigration regulation that took shape between 1882 and 1891 was created through contemporaries' efforts to reconcile these two "crises" with their cherished free labor worldview. The mostly Republican political intellectuals, policymakers, labor spokesmen, economists and others who were engaged publicly with the problem of mass economic dependency might have inquired into, and focused their efforts on redressing, the structural economic causes of the crises. Powerful critiques of the industrial labor system certainly were circulating at the time. ${ }^{9}$ Yet for free labor adherents, even to undertake such an inquiry would have been to admit the potential incompatibility of the wage contract-and the industrial labor system more generally - with independent, republican citizenship. Most GildedAge Americans were not disposed to surrender quietly their bedrock economic and political faiths. Rather than compromise the ideological integrity of the free labor ideal, they embraced a powerful alternative diagnosis, characterizing as deficient those who did not act in the marketplace according to their theory of human economic nature. ${ }^{10}$ In particular, contemporaries constructed the nation's successive crises of economic dependency as outbreaks of mass economic pathology, attributing widespread "pauperism," and later, "pauperizing labor," to the defective character of the poor themselves. That defectiveness, they

9. Examples of such programs were readily available in the 1880s. The Knights of Labor, for example, drawing on traditions of "labor republicanism," adopted an organizational strategy that emphasized both enhancing labor unions' power in the market, and gaining political power through electoral politics. See Forbath, supra note 6, at 787-88, 809.

10. As this statement suggests, the attribution of mass dependency to individual and group deficiency operated ideologically as an alternative to diagnoses centering on the labor system itself. While this characterization is generally accurate, it is important to acknowledge that a number of actors, most notably labor spokesmen, advanced both critiques concurrently. Compare $i d$., noting the Knights of Labor's advocacy of "structural" reforms of the labor system, with supra text accompanying note 177, describing Knights of Labor leader Terence Powderly's attack on degraded European immigrants as the source of labor market degradation. 
further concluded, was not home-grown, but rather imported from the allegedly effete, racially degraded, declining civilizations of Europe. ${ }^{11}$ By drawing on a series of highly specialized, frequently shifting ideas about racial difference, policymakers and others went a long way toward mediating an otherwise intolerable conflict between American values and American realities. ${ }^{12}$ The effect was to submerge a conspicuously unexceptional picture of industrial America into a discourse of economic pathology that associated foreignness with racial unfitness for free labor.

This emergent construction of European immigrants demanded a basic redirection of regulatory policy and practice. Within less than two decades, policymakers, immigration officials, courts, political journalists, and labor activists reconceived the principal purpose of immigration regulation from assisting newly landed immigrants to excluding undesirables and, accordingly, shifted its operational emphasis from policing the environment into which immigrants entered to policing the immigrants themselves. Moreover, under the weight of these new regulatory priorities, the robust federalism that had traditionally characterized the nation's approach to immigration gave way. Contemporaries' construction of mass dependency nationalized the purposes of immigration regulation, as a consensus emerged among influential northerners that the future of the American citizenry, the quality of citizenship itself, and, ultimately, the very health of the republic, were at stake.

Gilded-Age Americans thus began to articulate a fundamentally novel understanding of the American polity. In this new era of industrial consolidation, urbanization, and wage labor, the political-economic

11. The geographic origins of European immigration to the United States shifted dramatically between 1880 and the turn of the twentieth century. For the nation's first hundred years, the vast majority of Europeans arriving on American shores came from Great Britain, Ireland, Scandinavia, and Germany. Beginning in the 1880s, however, the proportion of northern European immigrants steadily declined and, by 1896, their numbers were eclipsed by the arrival of so-called "new immigrants" from Italy, Greece, Austria-Hungary, Poland, and Russia. See generally JoHN HIGHAM, STRANGers IN THE LAND: PATTERNS OF AMERICAN NATIVISM, 1860-1925 (1994); GWENDOLYN Mink, Old Labor and New Immigrants in american Political Development: Union, Party, AND STATE, 1875-1920 (1986). For a helpful overview of the economic and political structure of European immigration during this period, see JOHN BODNAR, THE TRANSPLANTED: A HISTORY OF IMMIGRANTS IN URBAN AMERICA 1-56 (1985),

12. It bears mentioning that the racial construction of European immigrants was just one prong of a much broader political and ideological impulse to constrict eligibility for citizenship. As a leading economist and amateur race scientist observed in 1896.

Each class or section of the nation is becoming conscious of an opposition between its standards and the activities and tendencies of some less developed class. The South has its negro, the city has its slums. ... The friends of American institutions fear the ignorant immigrant, and the workingman dislikes the Chinese. Every one is beginning to differentiate those with the proper qualifications for citizenship from some other class or classes which he wishes to restrain or exclude from society.

Simon Patten, The Theory of Social Forces, 7 Annals Am. Ass'N Soc. Pol. SCl. 143 (Supp. 1896), quoted in ERIC FONER, THE STORY OF AMERICAN FREEDOM 133 (1998). 
paradigm of self-sustaining households headed by independent male "producers"- the essential units of both traditional and "reconstructed" free labor ideology—appeared to be fading into history. In its place, contemporaries saw a vast reservoir of human material, consisting of the impoverished wage laborers and the unemployed who increasingly amassed in the nation's northern cities. They envisioned an American social and political body whose health depended, above all, not on the assimilative and uplifting influence of republican economic and political institutions, but rather on the collective natural endowments of its constituent members. The basic terms of the old free labor discourseindependence, virtuous citizenship, and the like-were not, strictly speaking, displaced by this new image, but infused with transformative new meanings.

Existing scholarship does not convincingly account for the timing, content, or legal consequences of the racial construction of European immigrants. ${ }^{13}$ Critical race scholars who have taken up the issue generally have applied an analytical framework that is poorly suited for this subject. ${ }^{14}$ The racial line of interest for such scholars typically is the line that has been drawn to distinguish "whites" from members of other, disfavored races. ${ }^{15}$ Perhaps accustomed to thinking about the legal history of race in the United States as a protracted dispute over the meaning and

13. Some have skirted the issue of race altogether. See, e.g., KITTY CaLAvita, U.S. IMMIGRATION LAW AND THE CONTROL OF LABOR: 1820-1924, at 41-71 (1984) (omitting mention of race in its analysis of Congress' efforts to control the supply of labor through immigration regulation); Roger Daniels, Guarding THE Golden Door: AMERICAN IMMIGRation POLICy AND IMMIGRANTS SINCE 1882, at 12-19 (confining its discussion of racialist nativism to that directed at Chinese immigration); E.P. HUTCHINSON, LEGISLATIVE HISTORY OF AMERICAN IMMIGRATION POLICY, 1798-1965, at 77-121 (1981) (quoting the explicitly racialist arguments advanced by restrictionists without addressing the issue); GERALD L. NEUMAN, STRANGERS TO THE CONSTITUTION: IMMIGRANTS, BORDERS, AND FUNDAMENTAL LAW (1996) (omitting discussion of race in its account of the Gilded-Age federalization of immigration regulation); Gunther Peck, Reinventing Free Labor: Immigrant Padrones and Contract Laborers in North America, 1885-1925, 83 J. AM. HIST. 848-71 (1996) (omitting discussion of race).

14. For an insightful review and critique of critical race scholarship, see Daniel J. Sharfstein, The Secret History of Race in the United States, 112 YALE L.J. 1473, 1478-84 (2003).

15. I do not wish to suggest that this choice of scholarly focus is inappropriate; indeed, it is well warranted by history. The policing of the color line-by communities, legislatures, and courtshistorically has carried enormous stakes for the individuals whose claimed racial identities, and thus social, political, and legal status, have been the subject of legal dispute. In the context of slavery and Jim Crow, for example, for many thousands of people the precise location of the color line meant the difference between slavery and freedom, or, after emancipation, between equal citizenship and the near-total civil and political disentitlement. See Cheryl I. Harris, Whiteness as Property, 106 HARV. L. REv. 1790 (1993). On whiteness trials in the slave and Jim Crow south, see Ariela J. Gross, Litigating Whiteness: Trials of Racial Determination in the Nineteenth-Century South, 108 YALE L.J. 109 (1998); Sharfstein, supra note 14. In the context of immigration, Congress' restriction of eligibility for naturalization, in the Naturalization Act of 1790, ch. 3, 1 Stat. 103, to "free white persons" similarly insured that the highest stakes, and hence the greatest legal contestation would attach to the adjudication of asserted claims to whiteness. See, e.g., IAN F. HANEY LOPEZ, WHITE BY LAW: THE Legal Construction of RACE 43-109 (1996); Annie M. Chan, Community and the Constitution: A Reassessment of the Roots of Immigration Law, 21 VT. L. REV. 491, 515-26 (1996). 
boundary of "whiteness," they have viewed the racial discourses deployed by restrictionists against Europeans through the lens of a fundamentally dichotomous racial landscape. As a result, these scholars tend to read latenineteenth and early-twentieth century assertions of a given group's racial inferiority to mean that the members of that group were not considered "white."16 This interpretation is highly misleading. However inferior the "racial" natures of Italians, Hungarians, Slavs, Hebrews, and others may have appeared when measured against an Anglo-Saxon ideal, the despised races of southern and eastern Europe nevertheless were, by most observers and in most contexts, regarded as "white." 17 Second, and more importantly, the near-exclusive focus on the construction and maintenance of the color line has caused scholars to neglect racial discourses that did not result directly in the political and legal disentitlement of the groups at which they were directed. This Article contends that although the racialization of European immigrants would not, until much later, ${ }^{18}$ culminate in the kind of group-categorical race legislation that was enacted against African Americans and Chinese immigrants, its consequences were nevertheless far-reaching with respect to the history of "race" in the United States. Acknowledging that European laborers could

16. One prominent example illustrates this tendency. In his seminal 1994 Article, "The Social Construction of Race," Ian Haney López addresses the racial construction of European immigrants through an historical lens adapted to tracking and deconstructing the ever-migrating color line between blacks, Asians, and Latin Americans, on the one hand, and whites, on the other. This framework leads Haney López to read the assertions of turn-of-the-century restrictionists and courts that Europeans did not comprise a single, monolithic white race to mean that members of at least some European racesthe inferior ones-could not have been considered "white" at all. Ian F. Haney López, The Social Construction of Race: Some Observations on Illusion, Fabrication, and Choice, 29 HARV. C.R.-C.L. L. Rev. 1, 34 (1994). See also Kevin R. Johnson, Race, the Immigration Laws, and Domestic Relations: A 'Magic Mirror' into the Heart of Darkness, 73 IND. L.J. 1111,1129 (1998) (noting that "southern and eastern European immigrants, commonly thought of today as white ethnics, were 'racialized' as non-white"); Ian F. Haney López, Race, Ethnicity, Erasure: The Salience of Race to LatCrit Theory, 85 CAL. L. REv. 1143, 1192 (1997) (referring to the historical racialization of today's "white ethnics" as "non-white").

17. Late-nineteenth and early-twentieth century policymakers, social reformers, social scientists, and others typically comprehended immigrants' attributes that they found objectionable-for example, their alleged slothfulness, sexual immorality, poor domestic habits, pathological economic behavior, and political radicalism-as hereditary, group-categorical, and sometimes ineradicable. Although Europeans frequently were characterized as members of distinct regional or national "races" in a way that the modern term "ethnicity" does not capture, they were not generally defined as "non-white." When contemporary scholars have been confronted with late-nineteenth-century references to Slav, Mediterranean, Iberic, Latin, Celtic, and Teuton "races," explains historian Matthew Jacobson, they have often wrongly dismissed such usage as a relic of a bygone era's misunderstanding of "race." MATTHEW FRYE JACOBSON, WHITENESS OF A DIFFERENT COLOR: EUROPEAN IMMIGRANTS AND THE ALCHEMY OF RACE 5-6 (1998). As Jacobson writes, an "accurate historical rendering of race in the structure of U.S. culture and the experience of those immigrants now called 'Caucasian," requires that contemporary scholars "admit a system of 'difference' by which one might be both white and racially distinct from other whites." Id. at 6 .

18. Although it provided for national quotas rather than outright "racial" exclusion, the Immigration Act of 1924 is properly understood as race legislation. See Mae M. Ngai, The Architecture of Race in American Immigration Law: A Reexamination of the Immigration Act of 1924 , 86 J. AM. HIST. 67 (1999). 
be adjudged unfit for inclusion within the American polity even as their "whiteness" remained culturally intact enables us to better recognize the subtle and not-so-subtle ways in which their racial construction underwrote the Gilded-Age federalization of immigration regulation. Further, by focusing on the production of racial difference within the category of whiteness, we see how the racialist nativism of the 1880 s and 1890 s helped to inaugurate in the United States a mode of political discourse in which the social and economic causes of poverty are effaced in favor of diagnoses centering on the alleged pathologies of distinct, often racially defined, groups. ${ }^{19}$ In important respects, the surge of nativism in the final decades of the nineteenth century parallels the North's retreat from southern Reconstruction and its relative lack of resistance to the rise of the Jim Crow system. In each case, racial difference gained sway as an argument for denying to the disfavored class full access to the American economic and political order.

Several scholars of American immigration law have taken the racial construction of European immigrants on its own terms. Two of the most sophisticated, Peter Schuck and Rogers Smith, insightfully analyze the apparent tension between the restrictionist discourse of racialist nativism, and the liberal republican worldview that informed the nation's longstanding liberality toward European immigration. ${ }^{20}$ Both argue, in

19. Since the late-nineteenth century, the seeming intractability of severe, politically disempowering economic inequality has stood as an unsettling contradiction for a nation committed to equal citizenship. By analyzing how influential Gilded-Age observers responded to the North's first encounter with mass economic dependency, this Article helps to illuminate how the United States has managed to live with that contradiction. For scholarship on contemporary parallels, see, for example, Douglas S. Massey and Nancy A. DENTON, AMERICAN APARTHEID: SEgRegation and THE MAKING OF THE UNDERCLASS 160-181 (1993); WILLIAM JULIUS WILSON, WHEN WORK DISAPPEARS: THE WORLD OF THE NEW URBAN POOR 51-86, 155-82 (1996).

20. Schuck explains that the Gilded-Age ideological shift "from traditional liberalism to restrictive nationalism, . . . reflected the influence of external pressures more than the internal logic of principle." PETER H. SCHUCK, CITIZENS, STRANGERS, AND IN-BETWEENS: ESSAYS ON IMMIGRATION AND CitIZENSHIP 24 (1998). Foremost among those "external pressures" was the dramatic transformation of the "ethnic, cultural, and class composition of the immigrant population ... between the 1870 s and World War I." Id. at 23. This transformation, Schuck maintains, "triggered the explosive passions of racial and religious prejudice, fears of revolutionary contagion, class conflict, and other deep-seated animosities against the newcomers . . . Powerful pressures to limit both the level of immigration and the rights of aliens consequently developed." Id. at 5-6. As a result, "nationalistic, exclusionary values were superimposed upon the earlier individualistic ideology of traditional liberalism." Id. at 21. Smith similarly characterizes Gilded-Age "ascriptivism"-his term for inegalitarian discourses that "assign[] people in hereditary hierarchical orders"-as a "repudiation of Reconstruction egalitarianism and inclusiveness." ROGERS M. SMITH, CIVIC IDEALS: CONFLICTING VISIONS OF CITIZENSHIP IN U.S. HISTORY 3, 347 (1997).

Schuck's metaphor-figuring racial prejudice as a kind of powder keg--rests on an overly simplistic conception of race and racism, and does little to explain either the timing or the content of the racialist nativism directed against the new immigrants. As this Article shows, the racial construction of European immigrants-not simply the fact that they were made the objects of racialist discourse, but the specific racial traits variably ascribed to them by their detractors-reflects not an "explosion" "triggered" by the self-evident ethnic or cultural "differences" of the new arrivals, but rather a direct reaction to the mounting ideological tension between liberal republicanism and the 
slightly different terms, that the ascription of racial unfitness to European immigrants gained political traction in the United States because it enabled political elites to cultivate a sense of national identity, or common "peoplehood," among citizens who were otherwise bound together only by liberal principles of consent. ${ }^{21}$ This interpretation, however, explains neither the sudden explosion of racialist arguments for restriction, nor the considerable variability of those arguments over a relatively short period of time. Why did European immigrants become the objects of such unfavorable racial construction when they did? Further, why did the cluster of specific racial attributes ascribed to Italians, Hungarians, Poles, and others shift so dramatically between the depression of 1873 and the passage of the Contract Labor Act in 1885? This Article argues that racialist nativism enabled contemporaries to reconcile their republican worldview with an economic landscape that increasingly called the sustainability of that ideological commitment into question. If racially inherited economic pathology was responsible for the dual crises of mass economic dependency, neither the industrial wage system nor the liberal economic theory on which that system was premised had to be reexamined. Mass dependency could be eradicated, and virtuous, independent citizenship restored, simply by raising new barriers of access to the American labor market. Free labor republicanism thus retained its moral and ideological viability by expunging from the market in wage labor, and thus from the liberal universe, those whose racial natures unfit them for free labor. By injecting a supplemented logic of racial

spectacle of mass economic dependency.

Other scholars similarly acknowledge the importance of racialist nativism to the federalization story, but omit any sustained investigation into the historical process through which the racial meaning ascribed to immigrants took shape. The Gilded-Age surge of racialist discourse is often represented as a straightforward, if exaggerated and irrational, response to the actual differences-in culture, language, or complexion-born by the "new" European immigrants. See KEITH FITZGERALD, THE Face of the Nation: Immigration, the State, and the National IDENTITy 108 (1996) (explaining that as immigrants" "skin darkened, as the languages they spoke became less familiar," officials lost faith in assimilation); ALEXANDER SAXTON, THE RISE AND FALL OF THE WHITE Republic: Class Politics ANd Mass Culture in Nineteenth-Century AMERICA 311 (1990) (asserting that when "the main sources of immigration had shifted from Western Europe to Southern and Eastern Europe, ... . [it] became possible to argue that the more recent immigrants-darker skinned and culturally more remote from Anglo-Irish-American norms-were, like the Asians, racially unassimilable").

21. As Schuck puts it, "the individual wills that liberalism glorifies must be merged into an almost mystical embodiment of national character and patriotic purpose." SCHUCK, supra note 20, at 78-79. In order for "liberal values to triumph, . . . liberalism [was] obliged to accommodate a competing, illiberal conception of community that threatens those values even as it promises to actualize them-albeit for only a limited portion of humanity." Id. at 79. Smith explains that GildedAge "leaders in both parties found that they could best gain support by responding to the fears and hopes of [the] era .... They promised to guard Americans against the new dangers from within and without via policies of restriction, exclusion, and mandatory assimilation ...." SMITH, supra note 20, at 348. See also DeSmond King, MaKing AMERICANS: IMMIGRATION, RACE, AND the Origins of DIVERSE DEMOCRACY 38-39 (2000) (endorsing Smith's analysis). 
contingency into their putatively universalist political economy, critics of liberal immigration thus ratified their worldview by narrowing its scope of application. $^{22}$

Part I of this Article argues that in the immediate postbellum period, the regulation of immigration into New York-the nation's primary port of entry-was animated by state officials' thoroughgoing confidence that European immigration represented an invaluable economic asset to the nation; that the overwhelming majority of immigrants were highly desirable as new additions to the American laboring population; and that by taking aggressive measures to protect newly landed immigrants against fraud and debilitating illness, New York best served the confluent interests of the state, the nation, and the immigrants themselves. Part II analyzes responses to the emergence of mass dependency in the nation's northern cities, between 1873 and the early 1880s. It argues that, even in the face of a crippling nationwide depression, contemporaries tended to attribute the economic crisis to a recent influx of "foreign paupers." Although critics of liberal immigration generally stopped short of rendering the kinds of racially categorical diagnoses that would become routine in the late $1880 \mathrm{~s}$ and 1890s, the discourse of foreign pauperism nevertheless began to transform the stated purpose of immigration regulation, and to build the case for federal control. Finally, Part III analyzes the claim, ubiquitous between the mid-1880s and the 1890s, that hordes of European "pauper laborers" were invading the American labor market. In contrast to the idle dependents of the previous decade, critics charged, foreign pauper laborers not only labored willfully for a wage, but did so with a vengeance that threatened to make a mockery of the ideal of free labor, and to destroy the

22. My analysis of the mutually constitutive relationship between the universalist premises of liberal republican political economy, on the one hand, and the rise of racialist nativism, on the other, has been greatly influenced by Thomas Holt's masterful study of post-emancipation Jamaica. See Thomas C. HolT, THE PROBLEM OF FReEDOM: RACE, LABOR, AND POLITICS IN JAMAICA, 1832-1938 (1992). Holt contends that for British policy elites, the emancipation of several hundred thousand black colonials was "a moment of truth in which the internal contradictions of classical liberalism stood exposed." Id. at xix. Holt explains:

$[F]$ ormer slaves ... who failed to respond to the market as they were supposed to were relegated to the status of wards of a superior civilization. Moreover, the fact that historically some of these same attitudes were also adopted toward white laborers who failed liberalism's test suggests that "racism" was embedded in the very premises of a presumptively nonracist liberalism; that the virulently racist ideology of the late nineteenth century was not merely some aberrant anachronism, or throwback to slavery, but in large part a creature of the ostensibly nonracist ideology that had undermined and destroyed slavery.

Id. at $\mathrm{xx}$. Ultimately, Holt concludes,

the defense of the 'natural' social order depended on how one understood ... human nature. Critical to sustaining social structures founded on blatant inequalities, within the terms of [liberal democratic] ideology, was the notion that some people-because of their fundamental racial natures-should be restrained, should not be free.

Id. at xxiii. In this way, "racialist ideologies came to be essential to sustaining the overarching ideology of freedom." Id. 
independence and virtue of "native" American workers. Through the discourse of pauper labor, I argue, contemporaries crystallized the construction of dependency as a consequence of group, and often racial, pathology, and then formalized that construction through the enactment of national exclusionary legislation. Although the Commerce Clause served as Congress' formal constitutional warrant for drawing immigration within the federal regulatory domain, Part III concludes that the underlying purpose of the new legislation was much closer to that of traditional state police regulations. Viewed in this light, the new federal regime looks less like a regulation of foreign commerce than an expression of an inchoate federal police power.

\section{FREE LABOR AND FREE IMMIGRATION IN THE EXCEPTIONAL REPUBLIC}

This Part analyzes the prevailing American view of European immigration before the Gilded-Age crises of mass dependency. It demonstrates how free labor republicanism shaped mid-nineteenth-century contemporaries' assessment and governance of European immigrants. Confident that free labor and republican institutions would transform the overwhelming majority of immigrants into virtuous, independent citizens, they cheered the new arrivals as a boon to the nation, and frequently even celebrated the commingling of foreign and native "blood." Immigration administrators, sanguine about immigrants' prospects for successful assimilation, understood their role to be primarily that of assisting and protecting the recent arrivals in order to preserve their independence-a regulatory outlook that they believed strongly counseled state, as opposed to federal, control. But before proceeding, it is important to explain briefly the rapidly changing ideological backdrop against which mid-century observers evaluated immigrants and immigration.

Although personal independence had been a deeply held economic and political ideal since before the nation's founding, its meaning evolved over the middle decades of the nineteenth century, as industrialization converted self-employed farmers and skilled craftsmen into wage earners, as workers and their families moved from self-owned farms into cities, and as the debate over slavery loomed increasingly large in the national consciousness. The emergence in the United States of a class of workers who would spend their entire lives laboring for a wage conflicted sharply with the nation's traditional model of male citizenship-a model that located the vaunted ideal of independence and the capacity for disinterested civic virtue and political participation in the ownership of real property. ${ }^{23}$ In western law, economics, and philosophy, the freedom to 
enter into commercial contracts had for centuries been associated with the sovereignty of the individual will and the formal equality of freely consenting, self-possessed individuals. ${ }^{24}$ The wage contract, however, was widely viewed as exactly the opposite-a relation of emasculating dependency. In Enlightenment philosophy, to labor at the behest of another constituted a forfeiture of economic independence; in common law, the wage contract was classified as a domestic relation. Indeed, for the first half of the nineteenth century hireling labor was widely believed to signify dependency and subordination. Hirelings not only surrendered the economic independence associated with property ownership and selfemployment; they subjected their personal autonomy and political will to the authority of their employer. ${ }^{25}$

In the postbellum era, for the first time in the nation's history a majority of male workers labored for a wage. ${ }^{26}$ Whether the status of such men was compatible with equal democratic citizenship became the paramount political and ideological problem of the decades following the Civil War. Although northerners superficially agreed on the superiority of free labor, that shared discourse disguised what was, in reality, a radical divergence of views concerning the essential conditions of freedom. ${ }^{27}$ Did the kind of self-sufficiency that could be had only from property ownership remain an indispensable component of true freedom, as republican theory had long held? Or, in the era of wage labor, did mere self-ownership, expressed through the sale of one's labor, suffice? Although some working men continued to contest the easy equation of personal freedom with liberty of contract, ${ }^{28}$ by 1870 that view was ascendant among congressional Republicans and political intellectuals. In the North and South alike, a man's capacity to enter into a wage contract, to alienate his labor for a price, became the principle hallmark of masculine freedom and

1872, at 25-44 (1981); GORDON WOOD, THE RADICALISM OF THE AMERICAN REVOLUTION 178 (1991); Ruth H. Bloch, The Gendered Meanings of Virtue in Revolutionary America, 13 SIGNS 37 (1987). On the transformation of labor generally in the nineteenth century, see ALAN DAWLEY, CLASS AND COMMUNITY: THE INDUSTRIAL REVOLUTION IN LYNN 11-96 (1976); BRUCE LAURIE, ARTISANS TO WORKERS: LABOR IN NiNETEENTH-CENTURY AMERICA 14-46 (1989); SEAN Wilenz, ChaNTS DEMOCRATIC: NEW YORK CITY AND THE RISE OF THE AMERICAN WORKING Class, 1788-1850, at $107-42$ (1984).

24. C.B. Macpherson, The Political Theory of Possessive Individualism: Hobbes to LOCKE 263-71 (1962).

25. Forbath, supra note 6, at 774; GLICKMAN, supra note 6, at 22-24; MONTGOMERY, supra note 23, at 30-33; DAVID R. RoEDIGER, THE WAgES OF WHITENESS: RACE AND THE MAKING OF THE AMERICAN WORKING CLASS 65-87 (1992); ROGERS, supra note 6, at 30-64; STANLEY, supra note 6, at 9-10; STEINFELD, supra note 6 , at $185-87$.

26. MONTGOMERY, supra note 23 , at 9-30.

27. See generally NANCY COHEN, THE RECONSTRUCTION OF AMERICAN LiberalisM, 1865 1914, at 29 (2002); GLICKMAN, supra note 6, at 99-107; STANLEY, supra note 6, at 60-97.

28. See ROGERS, supra note 6, at 153-81; STANLEY, supra note 6, at 60-97. 
independence, rather than a badge of feminized dependency. ${ }^{29}$

The conflict over slavery, as much as any other factor, transformed the cultural and ideological meaning of the wage contract. ${ }^{30}$ Abolitionists extolled the voluntary exchange of one's labor for a wage as the antithesis of slavery. The compulsion inherent in the slave system, they argued, violated the fundamental tenets of both economic morality and human nature, denying the right of man to govern himself, to enjoy bodily integrity, to own property, and to dispose of his labor at market price. ${ }^{31}$ Consent became the language of individual freedom, and thus acquired the moral and emotional weight of opposing human bondage. ${ }^{32}$ Slave emancipation and the victory of the Union Army further elevated the wage contract as the essence of freedom, individual economic agency, and male independence. The Civil Rights Act of 1866 enshrined this thinking in law, explicitly securing the right to contract for the sale of one's labor as an essential right of citizenship. ${ }^{33}$ This reconstruction of independence established the ideological terrain on which Gilded-Age Americans would confront the nation's crises of dependency, and the lens through which they viewed immigration. ${ }^{34}$

Before 1870, the prevailing posture toward European immigration to the

29. GliCKMAN, supra note 6, at 17-34; STANLEY, supra note 6, at 1-59. Over the last third of the nineteenth century, Lawrence Glickman explains, "It]he sale of the self for living wages became a paradigm of self-ownership and a symbol of modern masculinity." GLICKMAN, supra note 6, at 37.

30. Forbath, supra note 6, at 785-86; STANLEY, supra note 6, at 21 . On the antithetical relationship between slavery and liberal capitalism in abolitionist thought, see DAVID BRION DAVIS, THE MEANING OF SLAVERY IN THE AGE OF REVOLUTION, 1770-1823 (1975).

31. Ronald G. Walters, The ANTI-SLAVERy APPEAL: AMERICAN ABOLITIONISM AFTER 1830 (1978).

32. STANLEY, supra note 6, at 1-59.

33. ERIC FONER, RECONSTRUCTION: AMERICA'S UNFINISHED REVOLUTION, 1863-1877, at 244 (1988). As one congressman noted in the congressional debate over the bill, its purpose was to "secure to a poor, weak class of laborers the right to make contracts for their labor, the power to enforce the payment of their wages, and the means of holding and enjoying the proceeds of their toil." Id. at 244. On the meaning of wage labor in the Reconstruction South, see JuliE SAville, THE WORK OF Reconstruction: From Slave to WaGe laborer IN South Carolina, 1860-1870 (1994); STANLEY, supra note 6. This view of the wage contract by no means went uncontested, as northern labor spokesmen vigorously dissented throughout the 1870 s and 1880 s. See GLICKMAN, supra note 6 , at 17-25; MONTGOMERY, supra note 23; STANLEY, supra note 6, at 60-97.

34. Like contract freedom, "domesticity supplied a language for sectional conflict" (STANLEY, supra note 6, at 24), as the relative integrity of the northern household served as a basis on which to celebrate free labor and condemn slavery. For the Republican authors of Reconstruction, the rights of the freeman rested "on a conception of the family as an indivisible unit premised on male authority and female dependence." STANLEY, supra note 6, at 58. In the North, too, a deeply gendered ideology of domesticity became an essential component of working-class independence. A sharp conceptual distinction between the market-the masculine sphere of competitive economic exchange and productive labor-and the domestic-the feminine sphere of familial affection and selfless moral virtue- - "disrupt[ed] the analogy between wives and hired men" by positing a spatial and natural distinction between "women's dependent household labor [and] men's independent wage labor." Amy Dru Stanley, Home Life and the Morality of the Market, in THE MARKET REVOLUTION IN AMERICA: SoCial, POlitical, AND Religious EXPRESSIONS, 1800-1880, at 85 (Melvyn Stokes \& Stephen Conway eds., 1996). 
United States was one of enthusiastic celebration. In a nation that associated economic progress with the expansion of the skilled trades and the cultivation of undeveloped western lands, immigration supplied the indispensable raw material for an advancing civilization. As Carl Schurz, a rising star of the young Republican Party, explained to an audience in 1859 , the "American nationality" necessarily "incorporates the vigorous elements of all civilized nations on earth." While acknowledging that the "Anglo-Saxon spirit" had been the nation's traditional "locomotive of progress," Schurz urged his audience to remember that

this locomotive would be of little use to the world if it refused to draw its train over the iron highway and carry its valuable freight towards its destination; that train consists of the vigorous elements of all nations; that freight is the vital ideas of our age; that destination is universal freedom and the ideal development of man. ${ }^{35}$

Of course, such optimism did not go unchallenged. The 1850s were marked by an upsurge of anti-immigrant nativism directed mostly against the Irish, who had been arriving in unprecedented numbers since 1845 . The Know Nothing Party enjoyed brief but widespread electoral success in the mid-1850s by denouncing immigrants (particularly Catholics), and advocating a host of Draconian restrictions on immigrant suffrage, including lengthy naturalization periods and even post-naturalization limits on the franchise. ${ }^{36}$ Notwithstanding the currency of such sentiment, its influence was channeled primarily into proposals to protect the integrity of the vote, rather than efforts to limit immigration per se. The great weight of public and official opinion instead strongly favored liberal European immigration. ${ }^{37}$ For decades American business leaders had energetically promoted the virtues of free immigration. Industrial employers, such as railroads and manufacturers, dispatched agents to Europe and French Canada in order to recruit foreign laborers, while the United States Treasury Department and captains of American industry energetically calculated the economic value of free immigration to the national wealth. ${ }^{38}$

35. Carl Schurz, "True Americanism," speech delivered in Faneuil Hall, Boston, April 18, 1859, in IMMIGRATION AND THE AMERICAN TRADITION 121, 123-24 (Moses Rischin, ed., 1976). On the postbellum enthusiasm for immigrant labor, see HIGHAM, supra note 11, at 14-19.

36. See AleXander KeysSaR, The Right to Vote: The Contested History of Democracy IN THE UNITED STATES 82-86 (2000).

37. See generally DANIELS, supra note 13, at 6-7; William E. Forbath, "Who, the People?: Race, Class, and National Identity in the Law and Politics of European Immigration" (unpublished manuscript, on file with the author).

38. HighaM, supra note 11 , at 17. Andrew Carnegie, for example, estimated the average monetary value of each immigrant at $\$ 1,500$. Id. The federal government, too, actively encouraged immigration, particularly during the Civil War. Historian Kitty Calavita explains that in 1862, Secretary of State William Seward "saturated U.S. officials in Europe with pamphlets for distribution 
The New York Commissioners of Emigration (the Commissioners)the state agency that annually administered the admission of three-quarters of the nation's immigrants-agreed that immigration was both an invaluable economic resource and the embodiment of free, independent labor. Commissioner Friedrich Kapp, one of the nation's leading authorities on immigration, spoke for most of his contemporaries in 1870 when he explained that the United States "owe[d] its wonderful development mainly to the conflux of the poor and outcast of Europe within it"- to "the sturdy farmer and industrious mechanic" who through their "toils and sufferings . . . built up . . . the proud structure of this Republic, which in itself is the glorification . . . of free and intelligent labor." 39 In contrast to the indentured servants of the seventeenth and eighteenth centuries, who endured a form of dependence on their employers akin to bondage, the modern, independent immigrant relied "on his own strength, acts on his own responsibility, and seeks [prosperity] by his own efforts." ${ }^{40}$ The hearty independence and self-possessed economic agency of such immigrants were thus tributes to the values of free labor.

In characterizing the immigrant laborer as "his own master," immigration enthusiasts frequently contrasted him with the slave-the quintessential nineteenth-century symbol of bondage and dependency. It was "from no whim of the immigrant," wrote Kapp, "that he avoided the Southern States while they were cursed with slavery; for a land can have no civil liberty in which freedom of labor and the dignity wherewith respectable employment is invested do not exist." ${ }^{\text {"1 }}$ Reporting to the New York State Legislature on the unwillingness of recent immigrants to move to the former Confederacy, the Commissioners noted that the problem was especially acute in "the extreme Southern districts where there are only great planters, whose mode of cultivation has no attractions for the immigrants. [The immigrant's] individuality is overlooked, his self-respect

advertising high wages in the U.S. and publicizing the advantages of the Homestead Act." CALAVITA, supra note 13, at 36 . President Lincoln opened the 1864 congressional session by entreating Congress to establish

a system for the encouragement of immigration. Although this source of natural wealth and strength is again flowing with greater freedom than for several years before the insurrection occurred, there is still a deficiency of laborers in every field of industry. . . While the demand for labor is thus increased here, tens of thousands of persons, destitute of remunerative occupation, are thronging our foreign consulates, and offering to emigrate to the U.S., if essential, but very cheap, assistance can be afforded them.

CONG. GloBe, 38th Cong., 1st Sess., Appendices 1 \& 2, quoted in HuTCHINSON, supra note 13, at 48. In 1864, Congress passed the Act to Encourage Immigration, establishing the Federal Bureau of Immigration for the purpose of developing a surplus labor force. Though the Act was repealed in 1868 , during its short life the Bureau fostered the creation of a variety of private labor recruitment agencies that continued to encourage immigration. CALAVITA, supra note 13, at 41.

39. Friedrich Kapp, Immigration, 2 J. SoC. SCI. 1, 2 (1870).

40. Id. at 9,4 .

41. Id. at 10. 
impaired, and he is viewed as a mere unit in the mass." He was thus repelled by the prospect of joining the southern "stock of free slaves."

Commentators' celebration of the value and independence of immigrant labor was closely intertwined with their confidence in the nation's powers of cultural and political assimilation. Notwithstanding "the various manners, habits, and opinions of so many nationalities, some of them, if not repugnant, . . . at least strange to the native-born America," one writer marveled, "[t]he power of absorption possessed by the people of the United States is astonishing." "There is among those adopting our land as a home a tendency to assimilate," observed another. Through fraternization with "native" Americans and exposure to public education-a powerful "policy of insurance from our republican and protestant institutions"-immigrants are "liberalized, Americanized, and . . . [thus] grow up with the state, of the state, and for the state."

In stark contrast to the racialist nativism of later decades, mid-century theorists frequently extolled the nation's capacity to extract from immigrants their objectionable national and "racial" traits. "Columbia, taking to her ample bosom the fiery Celt and the phlegmatic Teuton, the self-asserting Briton and the debonnaire Gaul ... waits patiently for time and example to cure them," 45 one writer affirmed. Even the intergenerational transmission of distinctly foreign phrenological traits was thought to be disrupted by the United States' potent powers of assimilation. "The heavy features of the northern European are more or less elongated and brightened into thoughtful cheerfulness in his American child," this writer continued, "while the angularity and pugnacity supposed to be characteristic of the Celtic countenance are reduced to finer lines of grace and repose in their . . . descendants." ${ }^{46}$ Not only were immigrants' racially distinctive traits muted through assimilation; Americans' confidence in assimilation placed in doubt the very naturalness of those traits.

Some commentators even celebrated the incorporation of foreign traits as a positive benefit to the American citizenry. It was from the "widely compounded" material supplied by European immigration, the popular DeBow's Review editorialized in 1855, that the virtues of the United States grew. "And as the blood of every nation that treads upon the earth is throbbing in American veins, so it is no exaggeration to say that the

42. ANNUAL REPORT OF THE COMMISSIONERS OF EMIGRATION OF THE STATE OF NEW YORK FOR THE YEAR ENDING DECEMBER 31, 1869, at 108, 109 (1870).

43. The Philosophy of Immigration, 9 CATH. WORLD 399, 402 (1869).

44. Immigration; Its Evils and Their Remedies, 13 NEW ENGLANDER 262, 264, 274 (1855) [hereinafter Immigration; Its Evils].

45. The Philosophy of Immigration, supra note 43, at 402.

46. Id. at 404 (emphasis added). 
energy and enterprise of all the world bid fair to concentrate upon American shores." 47 In contrast to the "Anglo-Saxonism" that would predominate in the $1890 \mathrm{~s},{ }^{48}$ the article characterized racial "purity" as a distinct detriment to the human constitution. "[A] survey of the facts will show," it instructed, "that the purer the blood becomes, the nearer it approximates water, and that persons who can look up to the loftiest and remotest parentage, are usually gifted with the flightiest minds." ${ }^{49}$ If this "physiologic principle" is correct, the editorial concluded, "it follows that America pre-eminently owes its growth and prosperity to the amalgamation of foreign blood. To cut [it] off, therefore, or to discourage its influx, will be to check the current from which our very life is drawn." 50

Commentators expressed similar confidence in European immigrants' political assimilation. To the extent that newcomers presented a potential political risk at all, it was not due to any inherent unfitness for republican government-as many would come to believe in the mid-1880s and $1890 \mathrm{~s}$ - but rather because they might aggregate into unassimilated blocs, forming political commitments and sub-loyalties removed from the interests of the polity as a whole. As one author reassured his readers, immigrants are "naturally absorbed in the existing political parties." 51 To adopt the calls of the Know Nothing Party to extend the period of naturalization from five to twenty-one years would constitute "an affront to manhood. ... [S] uch proscription to a position of minority, inferiority, and presumed ignorance and hostility, would naturally work anything but an amicable and cooperative feeling toward their adopted government." 52 In other words, political danger lurked not with foreigners themselves, but in the imposition on immigrants of a common civil disability that might cause them to experience their condition as that of a subordinate class. A

47. Sources from Which Great Empires Come, 18 DEBow's REv. 698, 700-01 (1855) [hereinafter Great Empires]. The United States, the article argued, should follow the example of the great empires of the past. Greece sprang from a "horde of barbarous tribes"; the "introduction of ... foreign elements was like the descent of rain upon the barren earth." Rome was the product of a "parentage even more promiscuous and insignificant," where "in one mighty mass mingled conqueror and captive, noble and base, freeman and slave. Out of such materials, like some stately tree that roots best in filthy soil, in three centuries grew the republic of Rome." Id. at 699.

48. See HighaM, supra note 11, at 68-105.

49. Great Empires, supra note 47, at 702. See also Immigration; Its Evils, supra note 44, at 274 (arguing that colonial Americans were descended from high-quality material, rather than "aristocratic off-shoots" suffering from a "deterioration of the stock" as a result of "high cultivation").

50. Great Empires, supra note 47, at 704. Condemning the anti-immigrant sentiment of the mid1850s, DeBow's Review chided, "[w]hat, though the population which is annually cast upon American shores is all of the filthiest and most degraded kind! The farmer might as well complain of the black and reeking soil into which his seed is dropped, as the statesman of such materials as these." Id. at 704 .

51. Immigration; Its Evils, supra note 44, at 264, 273.

52. Id. at 273. 
broad cross-section of Americans thus celebrated immigrants not only for their labor, but also as a positive addition to the quality of the population. Throughout the postbellum period, this confidence-in immigrants' economic value; in the freedom and independence ascribed to their labor; in their cultural, racial and political assimilability; and in their contribution to the progress of the republic-led policymakers, administrators, and others to view control over immigration as a straightforward police function that fit comfortably within the province of state competence and authority.

The Commissioners' view that "the value of emigration from Europe cannot be estimated too highly," and accordingly, that the "encouragement of emigration by every possible means ... [was] a matter of the highest political necessity for the prosperity of the country," 53 directly shaped their regulatory priorities. Well into the $1870 \mathrm{~s}$, the Commissioners understood their primary mission to be that of providing a refuge and hospital for immigrants who arrived in New York destitute or sick, and protecting immigrants from being looted by thieves or defrauded by deceitful boardinghouse keepers, inland transportation companies, freight and luggage handlers, and employers. ${ }^{54}$ "The problem to be solved," wrote Commissioner Kapp in 1870, "was to protect the newcomer, to prevent him from being robbed, to facilitate his passage through the city to the interior, to aid him with good advice, and, in cases of most urgent necessity, to furnish him with a small amount of money." 55

Lest this relation of paternalistic care and protection be understood as a form of dependency on the part of newly landed immigrants, the Commissioners emphasized that their goal was in fact precisely the opposite-to preserve intact each immigrant's self-reliance. After recounting the various modes of assistance provided by the Commissioners, Kapp explained that to lend an immigrant such aid was "not to treat him as a pauper, with the ultimate view of making him an inmate of an Almshouse, but as an independent citizen." ${ }^{.56} \mathrm{He}$ continued:

For, whenever the poor immigrant is fleeced by rogues, his judgment is impaired, his energy is diminished, and in general that moral

53. ANNUAL REPORT OF THE COMmissioners of EMIGRATION OF THE STATE OF NEW YORK FOR THE YEAR ENDING DECEMBER 31, 1868, at 33-34 (1869).

54. FRIEDRICH KAPP, IMMIGRATION AND THE COMMISSIONERS OF EMIGRATION $63-84$ (1870).

55. Id. at 85. President Grant likewise endorsed the protection of immigrants as the primary goal of regulation. In his message to Congress opening the 1871 session, Grant urged: "The number of immigrants, ignorant of our laws, habits, etc., coming into our country annually, has become so great, and the imposition practiced upon them so flagrant, that I suggest congressional action for their protection." The following year, Grant sent a special message to Congress urging the protection of immigrants against "the knaves who are ready to despoil them." CONG. GLOBE, 42nd Cong., 2nd Sess. 3431 (1872), quoted in HUTCHINSON, supra note 13, at 61.

56. KAPP, supra note 54 , at 85. 
elasticity lost which he needs more than ever to start well in a strange land; and thus a heavy injury is inflicted on his adopted country, which, instead of self-relying, independent men, receives individuals who are broken in spirit, and, at least for a time, useless, who are burdensome to themselves and to others. ${ }^{57}$

According to this view, instances of dependency and vice among immigrants were not so much a foreign import as the result of immigrants' infection by the baleful influences they encountered upon arrival in New York. By protecting New York's newest residents, the Commissioners defended society less from a foreign menace than from its worst native elements.

The Commissioners' services were supported by the "Immigrant Fund," the source of which was, crucially, not the public purse, but the immigrants themselves. Under New York law, upon landing each immigrant was required to pay a small, non-refundable, commutation fee, known as "head money," which ranged over time between one dollar and two-and-a-half dollars. ${ }^{58}$ The immigrant who received assistance from the Commissioners, Kapp insisted, was "not a pauper, but a person legally entitled to protection by virtue of the payment of the head money." 59 The Commissioners rendered their services not as a form of charity; rather, Kapp explained, the "commutation fund is the consideration of a contract between the immigrant and the State of New York, by which the latter binds herself to protect him on his arrival, and for the period of five years thereafter provide him with shelter if destitute, and with medical and other aid if sick." 60 By characterizing the relationship as a contract-the preeminent postbellum symbol of economic freedom - the Commissioners preserved the appearance of immigrants' independence and self-reliance. ${ }^{61}$

57. Id. at 160 .

58. Id. at 97-98. After the United States Supreme Court held in The Passenger Cases, 48 U.S. 283 (1849), that a New York law imposing an outright tax on newly landed immigrants was an unconstitutional regulation of foreign commerce, New York revised the law to require instead that each and every foreign arrival post to the Commissioners a 300 dollar bond, which would be returned to the immigrant after five dependency-free years, in order to indemnify the state against the cost of his support. The sum was so high, the legislature knew, that the vast majority of immigrants would be either unwilling, or, more likely, unable to produce it. As an "alternative," the state permitted each immigrant instead to pay the commutation fee.

59. Kapp, supra note 39 , at 20-21.

60. Id. at $27-28$.

61. In so rendering the relationship, Kapp and the other Commissioners elided the fact that immigrants' payment of the head money was anything but voluntary-indeed, it was extracted by the Commissioners as a condition of landing. They also obscured both the staggering inequality in the parties' bargaining positions and the coerciveness of the bargain itself.

The Commission was at the forefront of redefining economic freedom in other ways, as well. The agency operated a formal "Labor Exchange," which, the institution's Superintendent explained, functioned as "a free market for every kind of emigrant labor, open to employers from all parts of the United States." ANNUAL REPORT OF THE COMMISSIONERS OF EMIGRATION OF THE STATE OF NEW YORK FOR THE YEAR ENDING DECEMBER 31, 1867, at 78 (1868). While to a skeptical postbellum labor 
The Commissioners insisted that the administration of the immigrant fund was a straightforward police function, and therefore the exclusive province of the State of New York. "The care of the immigrant, after he lands," wrote Kapp, "is purely a police regulation, in which the people of the State where he lands are so exclusively interested."62 Rejecting calls from some quarters for a "national board of emigration," Kapp contended that

[the] authority of the federal legislative power . . . ceases after the immigrant has landed and put himself under the operation and protection of State laws. For Congress to attempt ... to collect from him any tax, or to assume his support, would be not less absurd than if it were to undertake to license the boarding-house where he puts up. ${ }^{63}$

The Supreme Court's 1837 decision in New York v. Miln, ${ }^{64}$ confirming the state's authority to regulate the landing of immigrants, encapsulates the Commissioners' traditional position. The Court upheld a $1824 \mathrm{New}$ York law requiring ship masters to report all passengers' names, ages, and places of prospective settlement, as a proper exercise of the state's police function. In so holding, it decisively rejected a challenge to the law as an unconstitutional regulation of foreign commerce. The reporting requirement, observed the Court, was "obviously passed with the view to prevent [the state's] citizens from being oppressed by the support of multitudes of poor persons, who come from foreign countries, without possessing the means of supporting themselves." 65 In light of such a purpose, the Court could imagine "no mode in which the power to regulate internal police could be more appropriately exercised." 66 In 1837 , and, indeed, in 1870, pauperism was widely viewed as a local problem, "internal" to, rather than transcendent of, the jurisdiction of individual states. ${ }^{67}$ As Miln suggests, this was true regardless of whether the

unionist such a scene-particularly the image of employers "shopping" for the immigrant laborer of their choice-must have dramatized a morally objectionable commodification of labor, to the Commissioners it was a tribute to free labor. According to Kitty Calavita, such private labor exchanges, most of which "were concentrated in New York . . directly opposite the Castle Garden depot," were "the primary mechanism by which immigrant labor was distributed for several decades." The exchanges advertised and provided thousands of workers "at a moment's notice" for a fee of only one dollar, often at very low wages and to employers who used them as strike breakers. CALAVITA, supra note 13 , at $46-47$.

62. Kapp, supra note 39 , at 22 .

63. Id.

64. 36 U.S. 102 (1837).

65. Id. at 141 .

66. Id.

67. Twelve years later, in The Passenger Cases, the Supreme Court struck down a New York State law imposing a two-dollar tax on every immigrant, as an unconstitutional regulation of foreign commerce. The Court was highly fragmented, with each Justice in the five-Justice majority issuing a separate opinion. Yet even the opinion that expressed the most forceful determination to beat back 
pauperism at issue was of the ordinary, domestic sort, or a European import.

On the one hand, the Court's distinction in Miln between the circumscribed authority of the federal government and the comparatively expansive regulatory power of New York was grounded firmly in nineteenth-century federalism. Yet Kapp's strong advocacy of state-level control was animated at least as fundamentally by what he believed to be the Commissioners' main purpose-the protection of immigrants. "The transfer to the National Government of the control of the immigrant," Kapp wrote, "would . . . so increase the cost of supporting [him], as either to quadruple the present tax, and then make it virtually a prohibitory one, or to impose a burden on the national treasury, and thus make the immigrant the nation's pauper." If the immigrant's contractual relationship with New York were abrogated, Kapp worried, his dependency would become manifest. "[E]very cent spent from the national treasury for the immigrant can only injure his condition and the proper appreciation of his value. . . . One of the worse consequences" of such a development, he continued, "would be that immigration would speedily become a political question, and as such the subject of strife among demagogues, and that cry against the 'importation of foreign paupers' would doubtless be raised by which the condition of the immigrants would be deeply affected." 68 This reasoning makes explicit the conjoined ideological and institutional stakes of the Commissioners' construction of immigrants as independent. Any appearance of chronic dependency, they believed, could place political support for immigrants, and thus the state's capacity to protect them, in serious jeopardy.

In pleading their case to the nation, the Commissioners not only appealed to the public's concern for the well-being of the immigrants; they also linked their protection to the best interests of the United States. Kapp explained:

While New York has to endure nearly all of the evils, the other States reap most of the benefits of immigration. New York protects and shields the immigrant in his health and property, and rising communities of the West flourish upon the fruits of her vigilant care. Our state acts, so to speak, as a filter in which the stream of immigration is purified: what is good passes beyond; what is evil, for the most part, remains behind. Experience shows that it is the hardy,

virtually any attempt by the states to infringe Congress' exclusive authority to regulate foreign commerce conceded that a state could demand from immigrants a "security to indemnify the public should they become paupers.” Passenger Cases, 48 U.S. 283, 406 (1849) (McLean, J.).

68. KAPP, supra note 54, at 156. As this statement suggests, even in the era of relative confidence there existed a minority who attributed poverty to foreign pauperism. See supra text accompanying note 36 . 
self-reliant, industrious, wealthy immigrant who takes his capital, his intelligence, and his labor to enrich the Western or Southern States . . . [while a] large proportion of those who remain here is made up of the idle, the sickly, the destitute, the worthless, who would become a burden instead of a help to our people, were it not for the wise institution of [the immigrant] fund. ${ }^{69}$

The value that the nation reaped from immigration, in other words, was inextricably dependent upon the authority of New York to assist immigrants in their needs while preserving their independence. The administration of Castle Garden-the landing depot for all immigrants arriving in New York-was calibrated to do precisely that. The Commissioners believed that by extracting from immigrants a "premium on a policy of health insurance" 70 and in return providing assistance to those who required it-in effect, offering itself up as the nation's filterNew York performed a great service for which the nation should be grateful, rather than jealous.

\section{II. "FoREIGN PAUPERISM" AND THE EMERGENCE OF MASS DEPENDENCY, 1873-1883}

Concern over economic dependency was certainly not new in the Gilded Age. Government officials and relief workers in cities such as Boston and New York had confronted intermittent, if relatively brief, episodes of widespread poverty since the $1820 \mathrm{~s}-$ most acutely during the depression years between 1837 and 1842, and again in $1857 . .^{11}$ Before the 1870s, however, such economic downturns were viewed as aberrant and unnatural departures from an otherwise healthy and prosperous economy. It was only with the devastating depression beginning in 1873 that mass dependency began to be understood as a chronic, entrenched problem, and that it attracted the sustained attention of not only charity administrators and policymakers, but also political intellectuals, social scientists, and the middle-class public. $^{72}$ Since at least the early part of the nineteenth century, lawmakers, charity administrators, and economists had sometimes diagnosed poverty as an individual moral matter. They worried

69. KAPP, supra note 54 , at $157-58$.

70. Id. at 158.

71. Beginning in the late 1860 s, northern state legislatures enacted harsh anti-begging statutes, under which able-bodied men convicted of begging could be subjected to forced labor. Such measures, however, were less a response to mass joblessness per se than an attempt to symbolically shore up the often-porous boundary line between "honest" wage laborers and "dependent" beggars." See STANLEY, supra note 6 , at 98-137.

72. MiChaEl B. KaTZ, IN THE SHADOW OF THE POORHOUSE: A SOCIAL HISTORY OF WELFARE IN AMERICA 66-67 (1986); AleXander KeYsSar, OUT OF WORK: THE Ftrst Century of UNEMPLOYMENT IN MASSACHUSETTS 250-52 (1986); WALTER I. TRATTNER, FROM POOR LAW TO WELFARE STATE: A HISTORY OF SOCIAL WELFARE IN AMERICA 76-78 (5th ed. 1994). 
about the "pauperizing" effects of indiscriminate charity, sought to instill habits of industry, frugality, and self-sufficiency by extracting labor in exchange for alms and, from at least the $1840 \mathrm{~s}$, made the surveillance of poor families the cornerstone of "rehabilitation." 73 Yet for the first twothirds of the century, charity professionals and public commentators nevertheless retained a basic faith in the capacity of the vast majority of households to contain, or privatize, dependency. Charity administrators continued to work primarily through households, and instances of institutional care, though growing, were still viewed as exceptional. ${ }^{74}$

This Part describes the appearance in the 1870s of the first crisis of mass dependency, and analyzes its impact on northerners' understanding and governance of European immigrants. Section A describes how charity administrators and political intellectuals interpreted mass dependency principally as a moral, rather than an economic, problem, and blamed misadministered charity for sapping men's natural inclination to labor in support of their families. Most importantly, they identified poor households-long the basic units of republican independence-as the source of "hereditary" pauperism. This was a form of heredity, however, far more mutable and susceptible to reform than that of the coming decades. Section B demonstrates that charity administrators and others increasingly associated the apparent scourge of pauperism with European immigrants. As with the northern "pauper class" in general, however, such

73. KATZ, supra note 72 , at $40-42,165-66$; TRATTNER, supra note 72 , at $49-73,92-93$. The Victorian "casework method," under which female, middle-class "friendly visitors" regularly investigated the homes of aid applicants, was similarly premised on the assumption that poverty was primarily the result of a defective, immoral character, which could be "cured" through regular contact with one's social betters. See LORI D. GINSBERG, WOMEN AND THE WORK OF BENEVOLENCE: Morality, POLITICS, AND Class IN THE 19TH-CENTURY UNITED STATES 196-213 (1990).

74. Since the colonial period, policymakers had viewed the American population as disciplined through and supported by economically independent, self-governing families. This is not to say that the state took a laissez-faire approach toward family life. Local, colonial, and later state governments took an active roll in maintaining widows, orphans, the poor, sick, and others whose "natural" households had disintegrated through death, desertion, or economic failure. But provision was accomplished almost exclusively within the framework of private households-by, for example, granting subsidies to families who agreed to take in the sick or needy, apprenticing out orphans and the children of impoverished parents, and providing incentives to marriage and remarriage. In other words, the state promoted social and economic order by insuring that virtually every person was the ward of an adult male head of household - as a wife, child, servant, or otherwise. Even in the first half of the nineteenth century, when a variety of public and private institutions took on some of the social provision formerly performed through private homes, state policy toward poor relief and family governance continued to reflect a basic faith in the moral and economic viability of the nation's households as the self-sustaining units of society. On the colonial period, see ARTHUR W. CALHOUN, 1

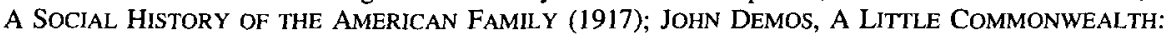
Family Life in Plymouth Colony (1970); Edmund S. Morgan, The PuRitan Family: Religion and Domestic Relations in SEVEnTEENTH-CENTURY NEW ENGLAND (1944). On the nineteenth century, see KATZ, supra note 72; TRATTNER, supra note 72. On the diminishing force of the "privatization" approach to dependency in the late-nineteenth and early-twentieth centuries, see Matthew J. Lindsay, Reproducing a Fit Citizenry: Dependency, Eugenics, and the Law of Marriage in the United States, 1860-1920, 23 L \& SoC. INQ. 541, 563-77 (1998). 
immigrants were not typically described in terms of intractable hereditary deficiencies. Finally, Section $\mathrm{C}$ argues that the discourse of foreign pauperism conspired with the Supreme Court's invalidation of New York's head-money system to transform official and popular understandings of the proper purpose and locus of immigration governance. As the broad presumption of republican fitness that had characterized the Commissioners' earlier work gave way to a new regulatory mandate-that of prohibiting the entry of the irredeemably unfit-pressure mounted to transfer regulatory authority from the states to the federal government.

\section{A. Economic Depression and the Moralization of Poverty}

The depression of the 1870s represented a watershed in the popular and political construction of dependency. The panic of 1873 inaugurated the most devastating economic downturn the United States had ever experienced, and the nearly six-year depression that followed left as many as a third of the nation's workers jobless. Charitable organizations were burdened with unprecedented throngs of jobless men, and the presence of adult, able-bodied heads of household begging in the streets became a disturbingly conspicuous symbol of social disorder. ${ }^{75}$ For the first time, the United States' historically professed classlessness and social mobility seemed genuinely vulnerable. The unique freedom and independence of American labor appeared to be in jeopardy, as desperation and dependency in the nation's cities invoked for urban observers images of the dreaded pauper hordes that plagued European capitals. For many northerners, such conditions portended the end of the young republic's immunity to the vicissitudes of industrial development-the end of the nation's presumed "exceptionalism."

Contemporaries noted the dependency not only of individuals, but that of entire households. ${ }^{76}$ Impoverished families became a potent symbol of the era's most disturbing trends-the jeopardy of household economic independence, the questionable moral and economic legitimacy of the wage system, the instability of traditional gender roles of male economic provision and female dependency, and the declining moral status of the home as a "haven in a heartless world." 77 The conspicuous failure of many

75. COHEN, supra note 27 , at 123 ; KEYSSAR, supra note 72 , at 57 ; STANLEY, supra note 6 , at 101-03; AlAN TRACHTENBERG, THE INCORPORATION OF AMERICAN: CULTURE AND SOCIETY IN THE GILDED AGE 39 (1982).

76. "Mature men who headed households and were expected to be primary breadwinners," writes one historian, "always constituted a majority of the unemployed." KEYSSAR, supra note 72, at 95.

77. The phrase comes from Christopher LATSCH, HaVEN IN A HEARTLESS World: THE FAMILY BESIEGED (1977). See also STANLEY, supra 6, at 138-74. The crisis of the working-class household was inseparable from what many contemporaries perceived as a broader assault on the 
poor and working-class families to contain and privatize dependency bespoke a degree of social and economic disruption far greater that that wrought by economic want alone.

A broad cross-section of Gilded-Age contemporaries-professional charity administrators, economists, labor leaders, journalists, and policy intellectuals-debated the causes of this crisis of dependency, and struggled to formulate appropriate remedies. Though it is clear in retrospect that mass unemployment was inseparable from a worldwide depression, declining prices, wage reductions, and frequent and long-term layoffs, a preponderance of (though by no means all) observers drew conclusions that pointed principally not to the structure of the industrial economy or the nature of wage relations, but to the character of the poor themselves. The crisis, they determined, was not fundamentally economic, but moral; and the enemy they confronted was not poverty, but pauperism-a very different, much more menacing, though potentially more manageable, phenomenon. Charles Kellogg, the Secretary of the New York Charity Organization Society and one of the leading charity experts of the day, explained that "[p]auperism is not poverty, however closely they may sometimes approach each other, for personal character makes a worldwide essential difference." 78 The distinction between an honest poor man and a pauper was a "distinction of character; a distinction

family. Growing numbers of working-class women were working outside of the home for wages; the woman movement was challenging the traditional legal regime of coverture; and advocates for women's suffrage and more liberal divorce threatened the marital unity and the patriarchal nature of middle-class homes. In reality, women's labor inside and outside of the home had been crucial to household economies, and to the nation's industrial expansion more generally, since the birth of the republic. It was the increasing visibility of this labor, often in the form of wage work performed outside of the home, that made it appear new to postbellum observers. On women's labor, see JEANNE BOYDSTON, HOME AND WORK: HOUSEWORK, WAGES, AND THE IDEOLOGY OF LABOR IN THE EARLY REPUBlic (1990); AliCE KeSSLER-HARRIS, OUT TO WORK: A History OF WAGE-EARNING WOMEN in the United States (1982); Christine Stansell, City of Women: SeX and Class IN New YORK, 1789-1860 (1987). On the woman movement's challenges to the patriarchal premises of coverture and divorce law, and to the exclusion of women from the franchise, see KEYSSAR, supra note 36, at 172-96; WILLIAM LeACH, TRUE LOVE AND PERFECT UNION: THE FEMINIST REFORM OF SEX AND SOCIETY (1980); Elizabeth B. Clark, Matrimonial Bonds: Slavery and Divorce in Nineteenth-Century America, 8 LAW AND HIST. REV. 25 (1990); Ellen Carol DuBois, Outgrowing the Compact of Our Fathers: Equal Rights, Woman Suffrage, and the United States Constitution, 18201878, 74 J. AM. HIST. 836 (1987); Hendrik Hartog, Lawyering, Husband's Rights, and 'The Unwritten Law' in Nineteenth-Century America, 84 J. AM. HIST. 67 (1997); Reva Siegel, Home as Work: The First Woman's Rights Claims Concerning Wives' Household Labor, 103 YALE L. J. 1073 (1994); Reva Siegel, The Modernization of Marital Status Law: Adjudicating Wives' Rights to Earnings, 1860-1930, 82 GEO. L. J. 2127 (1994).

78. D.O. Kellogg, Some Causes of Pauperism and Their Cure, 9 PENN MONTHLY 267, 280 (1878). Perhaps it was precisely because the employment of many workingmen was so precarious, and the boundary between familial self-sufficiency and dependency on charity so fluid, that contemporaries strove so intently in their representations of the economic scene to shore up the conceptual distance between those statuses. "The proud workingman," wrote Kellogg, "must be made to see that he is not confounded with the pauper. We must draw a broad line of distinction between penury and degradation, and by all means respect the independence and manhood of the artisan or laborer." Id. at 268. 
between self-respect and self-abandonment; between self-reliant industry and predatory idleness; between honor and shame."79

The crisis of mass dependency thus carried considerable ideological stakes. The "true science of political economy," wrote Kellogg, "must come, in the end, to a recognition of the fact that industry and commerce have a necessary dependence upon the laws of man's moral nature,- - that the development and welfare of the individual are the basis of productive power and of secure wealth." ${ }^{80}$ In Kellogg's free labor worldview, the satisfaction of workers' material and moral development, on the one hand, and the pursuit of industrial progress, on the other, were mutually dependent. Under the conditions of modern industry, no less than in the days of the artisan republic, Kellogg insisted, "utilitarianism . . . becomes the humanitarianism of John Stuart Mill." ${ }^{81}$ Far more than simply a social or economic problem, the mass dependency of adult men thus implicated the very laws of economic behavior and human nature that formed the philosophical and moral basis of both free labor ideology and the economic system on which the nation's industrial progress depended. Only by restoring the defunct moral and economic natures of New York's paupers could charity administrators like Kellogg ensure the continued compatibility of the nation's "utilitarian" and "humanitarian" impulses.

Although Kellogg and his colleagues generally agreed that the principle cause of pauperism was the pathology of paupers themselves, ${ }^{82}$ from what sources that pathology was born and of exactly what behaviors and dispositions it consisted were the subject of much speculation and debate. Theorists were virtually unanimous that misadministered charity was

79. Id. at 273. A few years later, Kellogg elaborated on this characterization:

Technically, a pauper is simply a person who has become dependent on the community. But a vast deal more is attached to the term in every mind. There is a type of character implied in it. A grave change, indeed, must have gone on in the individual character before a person's private trials can become subjects of public concern.

D.O. Kellogg, The Pauper Question, 51 ATLANTIC MoNTHLY 638, 639 (1883). It bears emphasis that this diagnosis derived directly from the internal logic of political economy, which northern reformers like Kellogg believed to be a mirror of human nature. As Nancy Cohen explains, "[e]conomic man proved himself in the competitive market." He "certified his worth by the prosperity he achieved for himself and his family." COHEN, supra note 27, at 33. According to this worldview, a man's character would be "judged according to how well he performed according to the norm of instrumentally rational, acquisitive economic man." $I d$. at 38.

80. Kellogg, supra note 78 , at 268 .

81. Id.

82. Unlike poverty, writes social theorist Giovanna Procacci, the construction of pauperism does not "work essentially through economic categories." Rather, by "grafting morality onto economics," pauperism appears "immediately as 'unnatural' as well as antisocial, a deformity which insinuates itself into the natural order which the discourse of political economy . . purport[s] to establish." Giovanna Procacci, Social Economy and the Government of Poverty, in THE FouCAULT EFFECT: STUDIES IN GOVERNMENTALITY, 158, 159 (Graham Burchell, et al. eds., 1991). When pauperism is "understood as a cluster of behaviors, a carrier of difference," id. at 164, the goal of charity becomes not the elimination of poverty, but the management of "different forms of conduct." Id. at 160 . 
largely to blame for compromising men's vulnerable moral natures. Indiscreet charity appeared to strike at the heart of the ideal of free and independent labor. As one observer wrote in 1877 , charity had been

educating some hundreds of thousands of men and women to habits of indolence, improvidence and dishonesty, and converting them into parasites and vermin, by lessening their motive to self-dependence, self-support and frugality. . . . In trying to help a man outwardly, we injure him inwardly-undermining his self-respect, weakening his will, confirming his faults. . . ${ }^{83}$

Moreover, a hasty "yielding to sympathetic impulses" not only degraded a man's individual character, explained another writer, but "means the destruction of the family, - the institution, above all others, upon which the happiness of mankind depends." 84 The New York State Board of Charities (NYSBC) - the state agency charged with coordinating the administration of public and private charity-thus urged the rigorous inspection of all recipients of out-door relief..$^{85}$ This included "frequent visitation, at their own homes... and a careful scrutiny into their resources, habits and capacities for labor." 86 Every case "must be examined, put on trial, and disposed of upon its merits," pleaded another commentator. "[W]e must learn to administer charity as through the courts of law we administer justice." ${ }^{87}$ The widespread advocacy and practice of such intense surveillance underscores the extent to which pauperism was viewed by contemporaries as a true social pathology, akin to an outbreak of disease, that threatened the very material and ideological bases of the

83. Charles G. Ames, Wisdom in Charity, 8 PENN Monthly 48, 52 (1877). The NYSBC echoed this view in its 1883 Report, explaining that "human nature is so constituted that no man can receive as a gift what he should earn by his own labor without a moral deterioration, and the presence in the community of certain persons living on public relief, has the tendency to tempt others to sink to their degraded level." STATE of NEW YORK, SEVENTEENTH ANNUAL REPORT OF THE StATE BOARD OF ChARITIES, 155 (1884).

84. D. McG. Means, The Suppression of Pauperism, 27 CENTURY 700, 702 (1884). In the logic of the Gilded Age, the preservation of men's economic character and the perpetuation of traditional gendered dependencies within the home were mutually dependent. Labor spokesmen embraced the nexus between a man's receipt of a living wage and the proper organization of gender within the household. To reconcile workingmen's status as hirelings with their claim to independent manhood, explains Lawrence Glickman, workers struck "a bargain with the wage system which would permit the patriarchal family to be kept intact" by demanding wages sufficient to comfortably support a family of dependents. GLICKMAN, supra note 6 , at 43 . "Living wages" would assure manly independence by "enabl[ing] gender to be reproduced within the wage system." Id. at 52.

85. In the lexicon of nineteenth-century charity administration, "out-door relief" referred to assistance afforded-in the form of coal, food, or, less often, cash-to people who continued to live in their own homes, as opposed to poorhouses.

86. New YoRk State, Eighth ANNuAl RePORT OF THE STATE BoARd of Charities 116 (1875) [hereinafter NYSBC, EIGHTH REPORT].

87. Ames, supra note 83 , at 53. On the rise of "social empiricism" generally in the nineteenth century, see Michael J. LACY \& MARY O. FURNER, THE STATE and Social Investigation IN BRITAIN AND THE UNITED STATES (1993). 
American free labor system.

Charity administrators sought to preserve and rehabilitate the economic character of their dependent clients by demanding labor in exchange for assistance. As the NYSBC urged in 1879, it "is a public duty to furnish labor to paupers on the ground of humanity. Man is so constituted, bodily and mentally, that happiness is found only in connection with constant and systematic labor." 88 The Report continued:

Labor, rigorously extracted from the pauper in proportion to his physical strength, contributes more than anything else to his wellbeing. He sees the results of his own labor taking shape day by day, and his self-respect is increased in proportion. . . . He acquires manual skills and the capacity for self-restraint and self-control. . . . $\mathrm{He}$ becomes conscious of a new accession of manhood, and . . . develops a desire to provide for himself, and to be his own master. . . . [L]abor is the best supplementary aid to moral teaching, and the best possible agency for the practical reformation of bad habits and character. $^{89}$

According to the NYSBC, by compelling charity recipients to work, their natural disposition to economic independence through voluntary labor could be rehabilitated. By locating the source of dependency in the degradation of individual character, yet upholding the potential for rehabilitation, such logic effectively assuaged the problem that mass dependency posed for both free labor and the theory of human nature on which it was premised.

Yet some charity administrators were beginning to wonder in the 1870 s whether the propensity for pauperism might not be inherited, as well as created. The last third of the nineteenth century witnessed the popularization of evolutionary naturalism, and, most significantly, the adaptation of the Darwinian theories of natural selection and survival of the fittest to sociological analysis. ${ }^{90}$ Although the "breeding war" between the classes heralded by Progressive-Era eugenicists remained two decades away, ${ }^{91}$ the discourse of hereditary deficiency provided many Gilded-Age analysts with a compelling framework with which to explain just what the epidemic of pauperism revealed about human economic nature. As the

88. State OF NEW YORK, TWELFTH ANNUAL REPORT OF THE STATE BOARD OF CHARITIES 261 (1879) [hereinafter NYSBC, TWELFTH REPORT].

89. Id. at 262. On the importance of compulsory labor, see also STATE OF NEW YORK, TENTH ANNUAL REPORT OF THE STATE BOARD OF CHARITIES 198 (1877).

90. On evolutionary naturalism and the popularization of social Darwinism, see PAUL E. BOLLER, JR., AMERICAN Thought IN TRANSITION: THE IMPACT OF EVOLUTIONARY NATURALISM, 1865-1900 (1969); Carl Degler, In SEARCh of Human Nature: The Decline and Revival of DarWINISM IN AMERICAN SOCIAL THOUght (1991); RICHARD HOFSTEDTER, SOCIAL DARWINISM IN AMERICAN THOUGHT (1944).

91. See generally Lindsay, supra note 74. 
NYSBC reported in 1875 , the Board's investigation had proved conclusively that "the great mass of our pauperism is hereditary. The fecundity of the class... is something frightful. Frequently three generations of paupers have been found in one alms-house." Unless drastic measures were taken, the Report continued, this "atavism of poverty and crime ... will go on in an increasing ratio for all time." 92 "From a small beginning," NYSBC Commissioner William Letchworth added, "a defective line of descent is established, which in the natural course ... expands into a sickly growth of pauperism, through succeeding generations ...."93

To argue that a trait was hereditary, however, did not necessarily imply the sort of intractable genetic determinism that the term invokes today. In the $1870 \mathrm{~s}$, the attribution of pauperism to defective heredity was in no way incompatible with the identification of "environmental" causes, such as misadministered charity. ${ }^{94}$ Most often, in fact, contemporaries believed that they worked in combination. ${ }^{95}$ Letchworth explained that even children born into a "defective line of descent" were

[from] the age of two to sixteen . . . forming character; their minds are plastic, and may be easily shaped to good resolves. The surrounding world is a school full of infinite teachings, and they are learning from it. These years of tenderness by their very nature seem designed by providence as a receptive period. After it has passed character becomes crystallized-the activities of life shut out the opportunities for improvement-[and] the mind does not so readily imbibe knowledge and form moral habits as in its early years. ${ }^{96}$

This variety of fluid hereditarianism furnished an appealing analytical framework for those who were determined to redress the problem of mass dependency, but who were not ideologically disposed to disturb their liberal belief in men's natural inclination toward economic independence and material progress. It offered a compelling naturalistic logic with which to pathologize pauperism, and it placed the source of dependency squarely on the shoulders of the poor themselves, where free labor adherents were

92. NYBSC, EIGHTH REPORT, supra note 86, at 108-109.

93. NYBSC, TWELFTH REPORT, supra note 88 , at 224.

94. On the compatibility and coexistence of hereditarian and environmentalist accounts of human behavior in the late-nineteenth and early-twentieth centuries, see Michael Willrich, The Two Percent Solution: Eugenic Jurisprudence and the Socialization of American Law, 1900-1930, 16 L. HIST. REV. 63 (1998).

95. Letchworth and his audience would have engaged such issues through the lens of the evolutionary theories of French naturalist Jean-Baptiste Lamark. Lamarkianism, to which most educated Americans still subscribed in this period, theorized that traits "acquired" during one's lifetime could be passed on to one's offspring. See generally DEGLER, supra note 90.

96. NYBSC, EIGHTH REPORT, supra note 86, at 175. See also Ely Van de Warker, Pauperism and Its Allied Offenses, 8 PENN MONTHLY 29 (1877). 
most comfortable to have it.

Finally, this fluid hereditarianism allowed charity professionals and others to make sense of mass pauperism while preserving intact their faith in social reform and the rehabilitation of individual character. They could express their declining confidence in the inherent viability of poor families as independent, self-sufficient social units, while simultaneously limiting the scope of their critique to problems that could be redressed by reforming the administration of charity. If degraded families were often the sites of "infection," the NYSBC reasoned, the appropriate remedy was clear. Under the subheading "Separation of Families not Always an Evil," the NYSBC reported in 1875 that it was

often found that the injudicious compassion of the dispensers of public charity has kept families together, when regard for the moral welfare of children and justice to tax payers, alike demanded that they should be broken up and the children taken from parents unworthy of them and placed in orphan asylums, or, what is better, in respectable families. ${ }^{97}$

That year the New York State Legislature passed a law requiring the removal of all children from poorhouses. ${ }^{98}$ Families that failed in their prescribed function of privatizing dependency not only lost their right of privacy, as in the case of households subjected to the surveillance of charitable agencies; under the discourse of hereditary pauperism, they lost their right to exist at all. ${ }^{99}$

The primary role of social conditioning in the creation of even "hereditary" paupers bears special emphasis here. In marked contrast to the construction of "foreign pauper laborers" beginning in the mid-1880s, the paupers of the 1870 s were believed to be not so much born as made; in the idiom of contemporaries, they were "educated," "encouraged," "converted," "habituated," and "degraded."100 Even born paupers, moreover, could be readily unmade, or cured, through intelligent conditioning: Habits and character could be reformed, self-respect restored, and children removed from the corrupting "hereditary" influence of their parents while they were still in their period of youthful "plasticity."101 In addition, by rendering dependency the archetypal social

97. NYSBC, EIGHTH REPORT, supra note 86 , at 108-10.

98. 1875 N.Y. Laws 173. See also David M. Schneider \& Albert Deutsch, The History of Public Welfare IN NEW YoRK STATE, 1867-1940, at 63 (1941).

99. On the conditionality of domestic privacy in the nineteenth century, see Nancy F. Cott, Giving Character to Our Whole Civil Polity: Marriage and the Public Order in the Late Nineteenth Century, in U.S. HISTORY AS WOMEN'S HISTORY: NEW FEMINIST ESSAYS 107-21 (Linda K. Kerber et al. eds., 1995).

100. See supra text accompanying notes 83-89.

101. See supra text accompanying notes $96-99$. 
pathology, Gilded-Age observers insured that "fitness"-for parenthood and for citizenship-would be measured by one's capacity for economic independence. They thus established a crucial and enduring element in the nation's understanding of dependency and laid the groundwork for the changing construction of immigration.

\section{B. Foreign Paupers and Hereditary Deficiency}

Along with negative conditioning and suspect heredity, charity administrators and others in the 1870 s increasingly noted the alleged "foreignness" of the dependent class. By invoking the image of "foreign paupers" flooding into the nation's cities, these critics named as the cause of mass dependency a source even further a field-in both ideological and geographical terms-from the home-grown, exceptional, American system of free and independent wage labor. Through the interrelated discourses of hereditary deficiency, bad social conditioning, and foreign pauperism, they began to lay the intellectual groundwork for what would become, in the mid-1880s, explicitly racialist explanations for dependency. "In all the countries of Europe," the NYSBC reported in 1875 , "the class of population that are [sic] paupers by inheritance is specially marked and easily recognized." 102 Through centuries of slavery and dependence upon the public bounty, "a great pauper class was formed throughout Europe from the residuum of ancient and medieval servitude." 103 The Report continued,

[p]olitical progress has wrought their personal freedom, but the weak and the ignorant among them yet retain the stamp of their far-off origin, and the habits which were engendered in their forefathers, who thronged to the doors of the monasteries to receive the proceeds of unwisely directed Christian charity, still cling to their descendants. Emigration has brought numbers of the pauper class from various foreign countries to our own shores .... [N]umbers, unchanged in character and tendencies, yet remain among us. They can be recognized by any thoughtful visitor to the homes of the poor, in our cities, and among the crowds who resort to the offices of the superintendents of the poor as eager applicants for out door relief. ${ }^{104}$

According to such accounts, members of this pan-European pauper class had been unnaturally selected for emigration to the United States precisely because they were the worst that Europe had to offer. Notably, the class included immigrants from European nations formerly believed to be the source of categorically desirable stock. One observer noted the recent

102. NYSBC, EIGHTH REPORT, supra note 86, at 109.

103. Id. at 112 .

104. Id. 
proliferation in the United States of English "tramps," a "species with which everybody is more or less familiar." "Neither they nor their fathers," he continued, "have lived by work for centuries past .... [T] specimens were born to the heritage of a pinched idleness." 105 This "new and strange race" 106 had perpetuated itself in modern times "partly by the propagation of vagrant children, who have stamped upon them, from before their birth, the vagrant instinct transmitted through several generations of vagrant ancestors."107

At first glance such language resembles the kind of rigid racialist hereditarianism that would dominate the debates of the mid-1880s. In the 1870 s, however, economic pathology was not typically characterized as an indelible endowment of foreign "races," as that idea would later be understood. As with the construction of pauperism generally, foreign paupers' hereditary inheritance did not necessarily seal their fates. Shortly after worrying about the "vagrant instinct" "stamped" upon the "strange race" of English tramps, the same writer argued that through forced labor, the "old poison in their blood, the hatred of honest toil, . . . [could] be sweated out of them, and their self-respect brought into wholesome action by the "movement cure." 108

Although foreignness itself was increasingly read as a marker of potential economic pathology, in the 1870 s neither immigrants as a class, nor immigrants from particular nations or regions, were characterized as inherently unfit for free, independent labor. To the extent that "foreign paupers" constituted a class at all, most commentators believed, it was one created by the hostile action of the European governments and almshouses responsible for their export. As the NYSBC observed in its first "Report on Alien Paupers" in 1875, the "practice of pouring the scum of a population - the criminal classes and confirmed pauper classes-into the territory of a friendly State, is an invention of the very latest years." 109 The "people of the United States," the Report insisted, "are not willing to support that class of indolent and hereditary paupers which have been smuggled into our country by the connivance or direct agency of foreign nations." 110 In marked contrast to the explicit racialism that would enjoy broad appeal just a decade later, in the 1870 s commentators attributed the plague of foreign paupers to the unnatural selection of degraded individuals for export, rather than to the irremediable endowments of

105. J.D., Tramps, Ancient and Modern, 6 PENN MONTHLY 886, 887 (1875).

106. Id. at 890 .

107. Id. at $890-91$.

108. Id. at 892 .

109. NYSBC, EIGHTH REPORT, supra note 86, at 141.

110. Id. at 137. 
national or regional races.

\section{Restricting the Free Flow of Immigration}

Fears of foreign paupers nevertheless began to transform both the prevailing estimation of many immigrants' value and views about how their landing and admission should be administered. Within a single decade, both the dominant political discourse of immigration and the old consensus about its governance underwent a dramatic reorientation. Policymakers, immigration officials, courts, political intellectuals, and labor spokesmen reconceived the principal purpose of immigration regulation from defending immigrants' economic and moral agency against fraud and illness to defending the nation against the depredations of unfit foreigners. Accordingly, regulators' operational priority moved from assisting immigrants along the pathway to independence to filtering out undesirables by expanding the grounds for exclusion.

The 1875 Supreme Court decision in Henderson v. Mayor of New York, ${ }^{111}$ declaring the New York head-money system unconstitutional, was an important catalyst in both the federalization of immigration policy and in refocusing it on the selective exclusion of foreign paupers. Writing for a unanimous court, Justice Samuel Miller emphatically rejected New York's argument that its bond requirement was "a suitable regulation under the power of the State to protect its cities and towns from the expense of supporting the persons who are paupers or diseased, or helpless women and children, coming from foreign countries." 112 European immigration had "attained [such] a magnitude and importance," reasoned Justice Miller, that it had "become a part of our commerce with foreign nations." 113 Administration of the commutation scheme thus constituted a regulation of foreign commerce, making it the exclusive province of the United States Congress. In a marked departure from the Court's reasoning in Miln, characterizing the regulation of foreign pauperism as a quintessential state police function, ${ }^{114}$ the Henderson opinion insisted that control over immigrants and immigration was, by its very nature, an essentially federal matter. "In addition to the wealth which some [immigrants] bring," Justice Miller wrote, "they bring still more largely the labor which we need to till our soil, build our railroads, and develop the latent resources of the country in its minerals, its manufactures, and its agriculture." 115 The Justice queried: "Can it be doubted that a law which

111. 92 U.S. 259 (1875).

112. Id. at 268 .

113. Id. at 270-71.

114. See supra text accompanying notes 64-67.

115. Henderson, 92 U.S. at 270. 
prescribes the terms on which vessels shall engage in [the transportation of this labor] is a law regulating this branch of commerce?"116

Yet elsewhere the opinion suggests that Justice Miller's redrawing of the boundary line between the federal government's and the states' respective spheres of regulatory dominion rested less on his constitutional understanding of foreign commerce than on a more worldly concern with foreign paupers. Under the New York system, he reasoned,

[t]he man who brings with him important additions to the wealth of the country, and the man who is perfectly free from disease, and brings to aid the industry of the country a stout heart and strong arm, are as much the subject of the tax as the diseased pauper who may become the object of charity of the city the day after he lands from the vessel. . . . No just rule can make the citizen of France landing from an English vessel on our shore liable for the support of an English or Irish pauper who lands at the same time from the same vessel. ${ }^{117}$

In other words, the mandatory payment of head money represented a tax on foreign commerce, as opposed to a police regulation, precisely because it failed to discriminate between desirable immigrants and paupers.

Kapp earlier had reconciled an immigrant's temporary receipt of public assistance with the long-term preservation of his independence by depicting aid furnished from the commutation fund as a form of insurance. Henderson now drove a conceptual wedge between any form of dependency and an immigrant's presumed capacity for robust labor. Miller's refusal to think of all immigrants as potential dependents, and his insistence on a sharp, categorical differentiation between immigrants disposed toward productive labor and those whose degraded constitutions predestined them for pauperism, testifies to how the association of economic dependency with inherited defects was beginning to infuse Gilded-Age political and legal culture. Further, both Henderson's legal result and Miller's particular reasoning suggest that the conception of poverty reflected in the robust federalism of the Miln decision-as a problem of strictly local dimension-was losing its descriptive and ideological salience in the new era of mass dependency. It simply no longer made sense in 1875 to talk about poverty as a socially, economically, or jurisdictionally discrete phenomenon. Rather, Henderson marks the way in which contemporaries were beginning to understand mass dependency as a problem with truly national implications for both the future of free labor and the quality of American citizenship. 
By invalidating the head-money system, Henderson thus affirmed the more general bifurcation of immigrants into those who were fit for free labor and those whose inherent deficiency destined them for lives of pauperism. At the same time, the decision devastated New York's capacity to fund immigration administration, and in doing so hastened its turn to the federal government as the preferred locus of governance. As the NYSBC observed in 1879 , without the head-money system, the state was unable to fulfill its protective mission:

It may suffice to say that this State still suffers from the influx of foreign paupers, idiotic, insane and criminals, and that the evil has assumed proportions of great magnitude, and is steadily on the increase. The decision of the Supreme Court of the United States in 1875 , denying the authority of a State to levy a per capita tax upon immigrants, has largely impaired the efficiency of the Commissioners of Emigration in protecting the State against the encroachment of these classes. ${ }^{118}$

The decision "affects not only the State of New York," the Commissioners explained, "but all other Atlantic states," effectively "throw[ing] their ports wide open and leav[ing] them unprotected" against the diseased and dependent. ${ }^{119}$

The termination of the commutation fund was thus an important catalyst in transforming the prevailing regulatory posture toward immigration. Not only did it lend the Court's intellectual weight to the discourse of unfitness; it also created a pragmatic problem of funding that spurred the NYSBC, the Commissioners, and the public in general to reconceptualize the meaning of even short-term dependency. The goal of the Castle Garden depot moved away from transforming temporarily needy immigrants into independent, vigorous laborers and toward denying entry to the defective class among them. In the future, the depot would serve less as an immigrant assistance agency, helping the needy along the pathway to independence, than as a carefully calibrated sieve, allowing the fit to pass through, while filtering out those whose present inability to support themselves evidenced not a need of temporary assistance, but an inherent deficiency of character.

Just a few years earlier both the NYSBC and the Commissioners had been emphatic that the authority to govern the admission of immigrants resided with the states, rather than the federal government. ${ }^{120}$ Now the urgent terms of the new regulatory discourse, in combination with New

118. NYSBC, TWELFTH REPORT, supra note 88, at 46.

119. ANNUAL REPORT OF THE COMMISSIONERS OF EMIGRATION FOR THE STATE OF NEW YORK FOR THE YEAR ENDING DEC 31, 1877, at 23-24 (1878) [hereinafter NYSCE, REPORT FOR 1877].

120. See supra notes $62-69$ and accompanying text. 
York's inability to fund its operations through the collection of head money, led both agencies to call for swift and aggressive national regulation. At the instruction of the New York State legislature "to impress upon Congress the necessity for speedy national legislation,"121 the Commissioners proposed a model federal immigration bill. In their appeal to Congress, they emphasized the traditional connection between the "benevolent" practice of securing immigrants "against frauds and depredations," and the great benefit that thus accrued to "those [regions] of the United States to which the tide of immigration flows." 122

Yet the model bill simultaneously suggested a marked departure from the Commission's traditional focus. The bill proposed that a national "immigrant fund" be appropriated by Congress and administered under the authority of the Secretary of the Treasury, who would have the power to contract with state boards to "take charge of the local affairs of immigration," including the inspection and assistance of immigrants. ${ }^{123}$ The master of every ship carrying immigrants would also be required to make a full report on each passenger and to "specify[] whether any of said passengers . . . are paupers or convicts, or are lunatic, idiot, deaf and dumb, blind, maimed or infirm and unable to support himself or herself; and, if so, whether they are accompanied by, or have relatives, ready, willing, and able to support them." 124 Most significant, however, was the Board's proposal that it be unlawful for any ship to land an immigrant who had been found guilty of a crime, or who,

within six months immediately previous to the time of such arrival, had been the inmate of any lunatic asylum, poorhouse, or other institution of a similar nature, or who had received public support or aid, or who, at the time of arrival was unable to support himself or herself, and was unaccompanied by or who had not relatives ready willing and able to support him or her; ... such person . . . shall not be permitted to land, but shall be ... taken back in and by such vessel ... to the country from which he or she may have been brought .... ${ }^{125}$

121. NYSCE, REPORT FOR 1877, supra note 119, at 17.

122. ANNUAL RePORT OF THE COMMISSIONERS OF EMIGRATION FOR THE STATE OF NEW YORK FOR THE YEAR ENDING DEC 31, 1878, at 23 (1879).

123. Id. at 26 .

124. Id. at 23 .

125. Id. at 24-25 (emphasis added). The growing urgency of the problem and the Board's changing emphasis were noted by contemporary observers. As The American reported in 1880, there was

a large element of our immigration made up of the most destitute and worthless persons to be found abroad. Even the Commissioners of Immigration [sic] admit that there is need of greater safeguards being established to protect the country from invasion by those people which any country can spare, and no country can afford to import.

Immigration, 1 AMERICAN 133 (1880). Another writer reported in the North American Review that as a general rule, the most valuable immigrants go West; while the sickly, the unenterprising, the 
This provision illustrates how the Commissioners', and, indeed, the nation's, understanding of both dependency and immigration was changing. Through it the Commissioners sought to nationalize the new regulatory trajectory away from shepherding newly landed immigrants through the transition from passengers to independent laborers, and toward a scheme of rigorous inspection and selective exclusion. Significantly, the provision made present or past receipt of public aid proof of unfitness. Dependency alone, in other words, was sufficient to warrant a presumption of undesirability. The provision thus reflected the emerging construction of paupers as a distinct type, whose material circumstances said something unmistakable about their fitness. This construction represented an important step toward imagining paupers not only as undesirable individuals, but also as constituting a defective class.

After several years of concerted lobbying by the New York Commissioners and by several state boards of charities, ${ }^{126}$ in conjunction with mounting public advocacy for national legislation, Congress passed the Immigration Act of $1882 .{ }^{127}$ The Act expressed unequivocally the central tenets of the Commissioners' model bill, locating the authority to regulate immigration in the Treasury Department, and empowering the Secretary of the Treasury to enter into contractual agreements with state commissions to "examine into the condition of passengers arriving at the ports." 128 "[I]f on such examination there shall be found among such passengers any convict, lunatic, idiot, or any person unable to take care of himself or herself without becoming a public charge," the law provided, "such persons shall not be permitted to land,"129 and the cost of their return shall "be borne by the owners of the vessels in which they came." 130 The Immigration Act thus placed the authority to regulate immigration with the federal government, just as the Henderson Court had instructed.

Yet the 1882 Act carried much broader implications, extending beyond constitutional and fiscal issues to the assessment of immigrants themselves. New York Republican John Van Voorhis, the bill's principal advocate in the House of Representatives, urged that while the landing of

vicious, and also those whose funds are exhausted, remain in New York. . . Is it to be expected, then, that the people of the State of New York will go on taxing themselves for the privilege of benevolently forwarding the better classes to the West, and retaining the inferior?

Edward Self, Why They Come, 134 N. AM. REv. 347, 365 (1882).

126. The Commissioners reported in 1881 that state boards of charities from Massachusetts, New York, Pennsylvania, Rhode Island, Michigan, Wisconsin, and Illinois had collaborated on model bills, which they had presented to Congress each of the previous two years. ANNUAL REPORT OF THE COMMISSIONERS OF EMIGRATION FOR THE STATE OF NEW YORK FOR THE YEAR ENDING DEC 31, 1880 , at 14 (1881).

127. Immigration Act of 1882, supra note 5.

128. Id. §1.

129. Id. $\$ 2$.

130. Id. $\S 5$. 
immigrants who "learn our language, adapt themselves readily to our institutions, and become a valuable component part of the body-politic" should not be checked, there had arisen "evils incident to immigration that can and ought to be avoided." Van Voorhis explained:

[Foreign] governments, ... societies, and individuals ... send to this country the dependent classes of Europe. . . . There is a strong tendency . . . to fasten upon this country the system of hereditary pauperism that exists in Europe. Indeed, the mass of our pauperism is already hereditary. Frequently in the State of New York three generations of paupers may be found in the same alms-house. This hereditary tendency is incurable. The fecundity of this pauper class is frightful. ${ }^{131}$

Although scarcely a decade earlier Kapp had celebrated the Commission's function as a national "filter in which the stream of immigration is purified," 132 by 1883 the Commissioners voiced a radically altered outlook. Just five months after Congress enacted the new law, they reported that many immigrants who pass through New York

settle in other States, and [then] become sick and destitute, or make but a feeble struggle for their own support, aware of the generous provision of the emigrant laws of this State, return in various ways to the Commissioners of Emigration to be cared for by the benevolence of the State of New York. . . . Why should the State of New York maintain its hospitals for the care of immigrants sent from other States which have derived the benefits of the healthy robust laborers, but impose on New York the burden of their unfortunate and helpless? Should the period of [support] be reduced [from five years] to one year only, the number of the destitute and helpless sent from other States to be cared for by this Commission would be materially diminished. ${ }^{133}$

To the extent that the 1882 Act relieved New York of the financial burden of administering Castle Garden, it thus also terminated the Commissioners' supposedly contractual obligation to provide assistance to the needy. In doing so, moreover, it converted even temporarily needy immigrants both inside New York and out into paupers. As a result, the

131. 13 CONG. REC. 5108 (1882). In support of his hereditarian claims, Van Voorhis cited the statements of a Dr. Martin B. Anderson:

Nothing is more unfounded than the common idea that the inmates of poorhouses in general are

the victims of avoidable misfortune. . . . [Their] voluntary degradation tends by a natural law to reproduce itself in all their descendents. This atavism of poverty and crime, unless broken in upon ... will go on in an increasing ratio for all time. Id.

132. See supra text accompanying note 68 .

133. ANNUAL REPORT OF THE COMMISSIONERS OF EMIGRATION FOR THE STATE OF NEW YORK FOR THE YEAR ENDING DEC 31, 1882, at 22-23 (1883). 
Commissioners' former commitment to protect immigrants against the baleful deceptions of New York's criminal class was eclipsed by its new role as the state's and the nation's sentinel of pauperism.

When the Supreme Court upheld the Act's fifty cent per capita tax in 1884 , its opinion both echoed the nation's growing anxiety about the fitness of its most recent arrivals and confirmed the police power function underlying the new federal regulatory regime. ${ }^{134}$ Although Justice Miller, again writing for a unanimous Court, lodged the holding technically in the Commerce Clause, his reasoning was unmistakably animated by a concern less with foreign trade than with foreign paupers. In addition to being "highly beneficial to the poor and helpless immigrant," he declared, the statute was "essential to the protection of the people in whose midst they are deposited." 135 Miller then announced, without any constitutional argument, that it was "equally clear" that "the power to pass such laws should exist in some legislative body in this country."136 Miller appeared incredulous that after holding in Henderson that the states lacked such power, the Court was now being asked to decide

that [the power] does not exist in Congress, which is to hold that it does not exist at all-that the framers of the Constitution have so worded that remarkable instrument, that the ships of all nations, including our own, can, without restraint or regulation, deposit here, if they find it to their interest to do so, the entire European population of criminals, paupers, and diseased persons. ${ }^{137}$

Miller's approval of the Act thus reflected the perceived necessity of filtering all new additions to the nation's population. The Act's provisions, the Court concluded, "are aptly designed to mitigate the evils inherent in the business of bringing foreigners to this country, as those evils affect both the immigrant and the people among whom he is suddenly brought and left to his own resources."138 The Court's language suggests the extent to which it imagined the Act as the expression-at least functionally, if not doctrinally - of a new type of federal police power, the declared goal of which was to protect the health and welfare of the national citizenry from an unprecedented external threat of corruption.

134. Edye v. Robertson, 112 U.S. 580 (1884).

135. Id. at 595 .

136. Id. at 591 .

137. Id. at 591 .

138. Id. at 595. 


\section{III. "FOREIGN PAUPER LABOR" AND THE POLITICAL ECONOMY OF RACE AND CITIZENSHIP, 1884-1893}

In its 1887 platform, the Republican Party dramatically announced that it was "unalterably opposed to the introduction of pauper labor into this country," and urged Congress "to pass such laws as will prevent the immigration of such peoples who will . . . come in competition with honest American laborers." 139 At first blush, such a statement may appear reminiscent of the widespread outcry during the depression of the $1870 \mathrm{~s}$ against the importation of foreign paupers. However, the curious phrase "pauper labor" suggests a divergent, even potentially contradictory, complaint. Pauper labor presented a problem that, in the mid-1880s, eclipsed earlier concerns about the failure of familial self-sufficiency and the corrupting influences of charity. As one Senate Republican explained in The Forum, a leading public affairs magazine, there is "a constantly increasing influx within our borders of classes of immigrants of a most undesirable character. The danger is the reduction of wages, to the injury of the American workman and his home and family, the debasement of the suffrage, and a wide contamination of society." ${ }^{140}$ The undesirable quality of such classes lay not in their dependency or refusal to labor for a wage, but rather in their willingness to labor for virtually any wage.

Like the earlier crisis of pauperism, the problem of foreign pauper labor threatened the ideological and moral legitimacy of the wage contract itself; it did so, however, in new and far stronger terms. Critics of pauper labor could not point to the education in idleness furnished to immigrants by misadministered charity, or to immigrants' inherited predisposition toward dependency. To the contrary, the immigrant pauper laborers of the 1880 s and 1890s not only labored willfully for a wage; they competed in the labor market with a vengeance that threatened to render meaningless the national celebration of free, independent labor. ${ }^{141}$

In doing so, immigrants posed to contemporaries the difficult task of explaining how free laborers competing in a free wage-labor market could degrade the industrial labor system. The Columbia University economist Richmond Mayo-Smith, one of the period's most-cited authorities on the

139. Immigration Again, 45 NATION 108 (1887) (quoting platform).

140. William E. Chandler, Methods of Restricting Immigration, 13 FORUM 128 (1892).

141. The tension between the idealized understanding of the wage contract as the essence of economic freedom and the alleged degradation of labor entailed in the importation of foreigners was no doubt exacerbated by the fact that those most responsible for the perpetuation of the contract labor system defended the practice as the embodiment of contract freedom. Historian Gunther Peck explains how "padrones"- the frequent middlemen between American employers and immigrant laborers in search of work-often sounded like "apostle[s] of liberty of contract," invoking the "hallmarks of 'free' labor relations-the wage contract and the right to quit-to create an extensive system of coercive labor relations." See Peck, supra note 13 , at 852,849 . 
economics of immigration, described the conditions that created this ideological problem:

[The] so-called unskilled labor of Europe crowds into the factories of America, crowding out labor that was intelligent if not actually skilled. . . . It is here that the American or the Americanized laborer is being subjected to the most strenuous competition. This labor from Europe . . . comes ready to take up any occupation in which it can earn a living. ... All the barriers of locality, distance, custom, and nationality have been broken down, and like the challenger of old he is obliged to face every new comer. His labor is literally a commodity, and he is paid the market value of it without any regard to its cost of production or its future supply. No one employs him because he is a man, or a neighbor, or a compatriot, but simply because he will take the least wages. The national pride in him and his work has ceased. ${ }^{142}$

Could the labor market be too free? Could the uninhibited alienation of labor be the source of its degradation? Economists such as Mayo-Smith, as well as politicians, charity administers, and political journalists, frequently answered such questions affirmatively. In doing so, they began to reevaluate a number of economic and social principles that had not warranted much scrutiny from the nation's political and intellectual elite since the end of the Civil War. They questioned the simple equation of contractual consent with economic freedom. They wondered whether the freedom to compete in the American market in wage labor should not be a circumscribed freedom, limited by, as Mayo-Smith put it, the "barriers of locality, distance, and custom." They even raised the possibility that the presumably universal laws of human economic nature on which the Gilded-Age gospel of free labor was premised were, in fact, not universal at all.

These were heady questions-about the nature of consent, the limits of freedom, and the laws of human economic nature-that bore directly on the moral and ideological integrity of the free labor system. Yet for its Gilded-Age adherents, free labor not only described an idealized economic world of liberal market relationships; it was also infused with the evolving republican values of personal independence and virtuous citizenship. The crisis of foreign pauper labor appeared to place these values, too, in grave jeopardy. By needlessly taxing public and private charity, the paupers of the 1870 s had allegedly thumbed their noses at productive labor and self-sufficiency. By now robbing "American" workers of the wages required to ensure for their families a civilized

142. Richmond Mayo-Smith, Control of Immigration, 3 POL. SCI. Q. 197, 223 (1888) (emphasis added). 
standard of living, the new economic pathology of pauper labor not only degraded the market in wage labor; it promised to destroy the very fabric of the republic-the respectability, personal independence, and political virtue of its citizenry. This pathology threatened to drive a conceptual wedge through the center of American free labor ideology, decoupling and rendering incompatible the citizenly virtues so essential to the political health of the republic, and the economic instrument on which the American industrial order depended-the wage contract.

Most contemporaries were not ideologically disposed to question either their bedrock faith in the utility and justice of the wage contract, or their republican political commitment to the preservation of a virtuous, independent citizenry. Nor could critics of foreign pauper labor attribute this new national bout of economic pathology to an "education in idleness" furnished by misadministered charity or to European schemes to rid the continent of the dregs of its population. Such explanations simply could not speak to the particular exigency of the new crisis-the pathology not of pauperism, but of pauperizing labor. Instead, critical attention turned almost exclusively to the hereditary endowments-the inherent difference-of pauper laborers themselves. Politicians, social scientists, charity administrators, and journalists adapted their constructions of difference to speak specifically to the new circumstances. As a result, their diagnoses of immigrants' allegedly pathological economic behavior - the hollowness of their consent, their willingness to labor under servile conditions for starvation wages, and their degraded standards of civilization-became focused almost exclusively on the alleged foreignness of its origins. Political intellectuals increasingly characterized the debased condition of foreign pauper laborers as one that was unalterably fixed from birth, impervious to reform or acculturation, and, most significantly, as the inexorable consequence of their national "racial" endowments. Rather than conclude that industrialization had set the American labor system and American citizenship on a collision course, these critics instead opted to refine the meaning and the scope of both. In the end, they determined that if liberal notions of consent, freedom, and economic nature no longer seemed to describe the behavior of a growing class of laborers, the solution was not to revisit those principles, but to exclude from the American market the people to whom they did not seem to apply - those whose apparently different natures set them outside of the liberal economic universe. Their remedy was to enact new eligibility requirements for would-be free laborers, and to usher in a new era of federal regulation.

This Part analyzes the northern critique of, and campaign to regulate, foreign pauper labor. Section A reviews the congressional and public debate that culminated in the passage of the Contract Labor Act of 1885 . 
That debate was, at bottom, a contest over the nature of personal independence, contractual freedom, and consent in the industrial era-that is, over the very meaning of free labor. Section B explores how critiques of European immigrants' pathological economic behavior merged with the proto-racial logic of evolutionary fitness. It argues that critics of foreign pauper labor transformed the fundamental terms of American political economy through the emerging discourse of American "civilization," supplanting the independent producer with the civilized consumer as the basic unit of good citizenship. Section $\mathrm{C}$ demonstrates how contemporaries lost their former faith in the assimilative powers of economic and political freedom, and concluded that European hordes threatened to contaminate not only the American wage labor market, but also the racial fitness of the citizenry. Finally, Section D argues that from the debates over the successive Gilded-Age crises of dependency and foreign pauper labor there emerged a fundamentally novel understanding of the American citizenry. The health of this new national body would depend less on the uplifting influences of American values and institutions than on the quality of its "stock." This new image, moreover, operated as a key premise of an inchoate federal police power.

\section{A. What is "Free Labor"?: The Contract Labor Act of 1885}

The heated public and political debate over the problem of foreign pauper labor centered on how best to protect the republic against, as one Republican Senator put it in 1885, a loathsome "class of contracts that have sprung up in the last eight or ten years." 143 Kansas Republican Preston Plumb explained the practice of "foreign contract labor" and its attendant evils to his colleagues: "While the United States Government opens its doors to all voluntary immigration, it should most unequivocally close its doors against all involuntary immigration, or against any immigration which comes in here under contracts to labor for a period of years." "Such immigration, such labor" was, in Plumb's estimation, "to all intents and purposes slave labor, and it can under no circumstances do anything else than degrade and debase free American labor." 144

Led by Ohio Democrat and former union president Martin Foran, Congress obliged calls for legislation-calls not only by legislators, but also by labor spokesmen, economists, and journalists of diverse political stripes-and passed the Contract Labor Act of 1885, which President Cleveland promptly signed into law. ${ }^{145}$ The Act provided:

143. 16 CONG. REC. 1785 (1885) (statement of Sen. Warner Miller).

144. 16 CONG. REC. 1778 (1885).

145. Contract Labor Act of 1885, supra note 5. Although the Act drew support from a relatively wide range of ideological constituencies, its principal political impetus, as well as its actual text, came 
[It] [s]hall be unlawful ... to prepay the transportation, or in any way assist or encourage the importation or migration of any alien or aliens, any foreigner or foreigners, in the United States, . . . under contract or agreement .. made previous to the importation or migration of such alien or aliens, foreigner or foreigners to perform labor or service of any kind in the United States . . . 146

The law, which was also known as the Foran Act, was rendered nearly ineffectual by poor funding, weak enforcement mechanisms, hostile treatment by the federal courts, and the fact that only a small fraction of European immigrant laborers actually arrived in the United States "under contract." 147 The national debate surrounding its enactment nevertheless proved to be an indispensable chapter in the evolution of free labor ideology, the construction of "pathological" economic behavior as a racial trait, and the federalization of American immigration law. Opponents of contract labor were tasked with explaining how, if the wage contract was the preeminent instrument of individual economic freedom, European workers who traveled to the United States after having consented to labor for a particular employer for a given wage and duration, could be guilty of "degrad[ing] and debas[ing] free American labor." 148 The mostly southern, Democratic, congressional opponents of the Contract Labor Act appeared to revel in what they suggested was the ideological inconsistency of the Act's "free labor" proponents. Senator John Morgan, an Alabama Democrat and former Confederate General declared, "there is no more vicious system of legislation that has ever been conceived of . . than that of converting the obligation of a contract or the making of a contract into a crime." "Contracts in some form attend almost every act of our social and domestic relations," he continued, "and to denounce those as crimes that are in themselves innocent is to endanger every relation and duty of life." 149 Morgan and several of his allies intimated repeatedly that the very

directly from the labor movement. A Knights of Labor attomey drafted the statute, and the Knights recruited Congressman Foran, a former union president, to sponsor the legislation. See FITZGERALD, supra note 20, at 116; Forbath, supra note 37.

146. Id. $\$ 1$.

147. On the ineffectiveness of the 1885 Act, see CALAVITA, supra note 13, at 52-66. William Forbath notes that courts narrowed the Act's scope of application by holding that arrangements between employers and would-be immigrant employees that fell short of formal contracts did not violate the Act's prohibition against contract labor. See Forbath, supra note 37.

Gunther Peck intriguingly suggests that the Act may even have exacerbated the problem of contract labor. By "creating hurdles" for immigrants who had already secured a job before entering the United States, Peck writes, "the Foran Act actually increased the need for immigrant middlemen to help guide workers across the border. The more rigorously the Foran Act was enforced, the more stature padrones gained in the eyes of American corporate officials by their demonstrated ability to circumvent the law's requirements." Peck, supra note 13, at 854.

148. See supra text accompanying note 144.

149. 16 CONG. REC. 1631-32 (1885). Morgan continued: "[I]t is vicious legislation . . . because it violates the traditions of the Anglo-Saxon race in legislation by converting the ordinary and natural 
same legislators who just two decades earlier had been so eager to strip the South of its oppressive, status-encrusted social and economic system and to usher in a liberal regime of consent and contract were now committing the worst kind of hypocrisy.

Congressional proponents of the Act-a coalition of Republicans and northern, pro-labor Democrats (a number of whom had previously held union leadership positions)—responded that laborers "imported" under contract lacked the volition requisite for meaningful consent. Contract laborers were moved to immigrate not by the freedom of their wills, they argued, but rather at the initiative of American employers. Michigan Republican Byron Cutcheon maintained that the legislation was designed "to exclude the ... degraded . . . [and] almost servile laborers who come here moved not by the healthy normal impulse, but incited and instigated by the mercenary agents of corporations." 150 A young Theodore Roosevelt similarly urged "that as bread grows cheaper human flesh should be dearer." "The capitalist who aids in the importation of cheap labor, with a view to increasing "competition in the labor market," he chided, was a "dangerous enemy to society. .. . The man who imports degraded laborers is also importing unworthy citizens; and is therefore committing a peculiarly contemptible species of treason against the Republic."151 Roosevelt's references to "importation" reflect the growing view that contracts formed prior to immigrating deprived foreign laborers of meaningful agency. For such critics, the mere fact of a contract no longer signified unequivocally a laborer's freedom and independence. Further, by placing the phrase "competition in the labor market" in quotation marks, Roosevelt suggested the extent to which the crisis of pauper/contract labor had prompted contemporaries to critically reevaluate the meaning and consequences of free, unfettered competition.

True contractual freedom, urged congressional proponents of the Contract Labor Bill, required a type of informed consent that could only be had through first-hand knowledge of American economic and social conditions. Representative Foran explained that the "species of immigration with which this bill seeks to deal" is comprised of men who

rights to make a contract into a crime." Id. at 1632.

150. 15 CONG. REC. 5369 (1884).

151. Theodore Roosevelt, The Immigration Problem, 7 HARV. MONTHLY 85, 86-87 (1888). Labor advocates similarly placed the initiative for immigration under contract solely on the employers. Terence Powderly, the labor spokesman most frequently cited by members of Congress, insisted that, if immigrants were to prove "beneficial and healthy" to the nation, they must come "of their own volition." Terence V. Powderly, A Menacing Irruption, 147 N. AM. REv.165, 165 (1888). Instead, he bemoaned, a very large class "come[] here under contract or after undue influence has been brought to bear on them by agents of American employers." Id. at 168. "They come as paupers," Powderly continued, "and as paupers they remain; they come to compete in the struggle for food with the American workman." Id. at 169. 
do not come "of their own volition," and who "perhaps had never heard of America; they certainly know nothing of our institutions, our customs, or of the habits and characteristics of our people." 152 Senator James George, a Mississippi Democrat, similarly instructed that the "difference between servile labor or slave labor and labor performed under a contract made with an ignorant foreigner, unacquainted with our language, unacquainted with the price of labor here, is very little in practical effect." 153 For these legislators, formal consent was insufficient; true volition required specific knowledge not only of the labor market into which immigrants were entering, but also of the "customs" and "habits" of American laborers.

As such statements indicate, the contest over contract labor was, at bottom, a debate over the precise meaning of free labor. Far from backing away from their rhetorical and ideological commitment to the wage contract, the bill's proponents presented the legislation as a necessary defense of free labor against the threatened restoration of a new form of bondage. Few advocates of the legislation could resist invoking the analogy between foreign contract labor and chattel slavery. The enactment of the Contract Labor Bill, they argued, would be but the latest victory in the historical struggle to ensure the freedom of all labor. It is "part of a great work in which I have been engaged here for the last twenty-five years," declared Senator Plumb, "that all labor in this country shall be absolutely free." "He who sells his effort sells his life. He who ties his hands," Plumb dramatized, and "winds about the muscles of his body the chains of a contract made abroad, is a slave, and it is against slavery that this bill is aimed." 154 Just as abolitionists and the architects of Reconstruction earlier had forged the wage contract into a token of freedom, Gilded-Age critics of contract labor invoked the image of human bondage once again to refine the meaning of free labor. ${ }^{155}$

Critics of contract labor contended that in times past the very act of immigration had itself entailed a certain test of individual fitness for the

152. 15 CONG. REC. 5349 (1884).

153. 16 CONG. REC. 1794 (1885).

154. 16 CONG. REC. 1783 (1885). Such statements were ubiquitous in the congressional debate over the Contract Labor Bill and in leading national publications.

155. Further, for such critics the economic dependence of unskilled, poorly paid industrial hirelings translated directly into their dispossession of political will. Terence Powderly, among others, raised the specter of "raw, undisciplined, willing serfs . . . being used as voting instruments which neutralize the best efforts of patriots." Dependent, foreign workers were "more docile," Powderly explained, "and though they may never be able to understand the English tongue, if they become citizens they will know how to vote as the owner of the mill wishes." Powderly, supra note 151, at 173. In one company, he recounted, new hires "were told by the owner of the mill that he expected they would vote in accordance with his wishes." Id. at 171. Notably, even many employers, who had long trumpeted the economic benefits of free European immigration, joined the restrictionist chorus. Confronted with mounting labor conflict and union militancy in the mid-1880s, business leaders increasingly identified "foreign radicals" as the source of the unrest, and viewed immigrants as potential agents of economic and political instability. HIGHAM, supra note 11, at 52. 
American market in competitive labor. In recent years, however, the severity of the conditions that compelled many desperate Europeans to immigrate to the United States had, along with the assistance furnished by American employers, abrogated that vital test. Railroad president and future Secretary of the Treasury William McAdoo insisted that the unemployed European laborer was, "without choice or provision, . . . chased by starvation and necessity, together with his more wretched family, into the crowded hold of a great steamship." ${ }^{156} \mathrm{He}$ continued:

Such an immigrant is forced to come ... out of the pain and pinch of a necessity which our [tariff] laws have forced upon him.

Frequently he becomes a chattel, a serf, with a number instead of a name, a piece of brutalized, degraded, human machinery, consigned in a freight car to some great corporation. ${ }^{157}$

Such immigrants, McAdoo suggested, were not the industrious, freedomloving, independence-seeking workers that Commissioner Kapp had celebrated just two decades earlier. They were virtual chattel, evacuated of agency and individuality by forces beyond their control.

Critics of pauper labor likewise worried that the relative ease and low cost of migrating to the United States had removed an important trial of economic fitness. Francis Amasa Walker, perhaps the era's preeminent political economist and the future Chief of the United States Census Bureau, explained that an improved European railway system and the lowering of the price of passage to the United States had "reduce[d] almost to a minimum the energy, courage, intelligence, and pecuniary means required for immigration." The result, Walker feared, was a class of immigrants comprised "no longer [of] the more alert and enterprising members of their respective communities, but rather the unlucky, the thriftless, the worthless." 158 Mayo-Smith described the problem in explicitly Darwinian terms: "The process of natural selection which the difficulties of the voyage formerly brought about, no longer works. Practically any one can now go . . . ." 159 Degraded laborers who immigrated with such unfortunate ease "can scarcely be said to be following out natural economic impulses leading them to better their

156. William McAdoo, Immigration and the Tariff, 11 FORUM 398, 402 (1891) (emphasis added).

157. Id. at 402 (emphasis added).

158. Francis A. Walker, Immigration and Degradation, 11 FoRUM 634, 643 (1891). The immigrant's "arrival at our shores," explained another critic, "no longer proves anything in favor of his character." Only a "few dollars," he continued, "stand in the way of any inhabitants . . . from the most degraded cesspools of the world's population, coming to this country." Noble Canby, Immigration, 16 CHAUTAUQUAN 197, 198 (1892).

159. Richmond Mayo-Smith, Control of Immigration, 3 POL. SCI. Q. 46, 76 (1888). 
condition and thus indirectly to benefit the world at large." 160 The trope of unnaturalness in this passage is significant. By attributing immigrants' allegedly pathological economic behavior to the unnaturally selected deficiencies of their character, Mayo-Smith elaborated one of the key ideas according to which the old, eroding "barriers" around the free labor market would be affirmatively reinforced. "For the country receiving the immigrants," Mayo-Smith continued, "it is a misfortune that this natural selection has fallen away. To go on receiving them, without check or control, is like attempting to guide a heavily loaded wagon down hill, with the wheels greased and the brakes off, because it had been done before successfully with the brakes on."161 Congress did indeed reapply the "brakes," and calibrated them with an eye toward the perceived racial unfitness of particular national groups.

\section{B. Citizenship and Civilization: Discovering the "American Standard of Living"}

The understanding of hereditary unfitness articulated in the 1880 s and 1890 s drew in part on existing theories about the inheritability of economic pathology. The construction of pauper laborers as members of categorically suspect national groups nevertheless marked an important conceptual departure, insofar as it folded immigrants' allegedly "unnatural" economic behavior into a proto-racial discourse of evolutionary fitness. Critics of foreign pauper labor increasingly judged would-be free laborers against the emergent notion of "civilization." As the previous Section demonstrated, the eroding thrift and industry among immigrants that charity administrators in the 1870 s were so concerned to rehabilitate returned with a vengeance in the crisis of pauper labor. "The trouble," Mayo-Smith explained, "is their economy does not stop at a point where it would be desirable." Instead, "[t]heir standard of life is one which it would be a serious misfortune for the American laborer to imitate. Their wants have been reduced to a point where low expenses no longer indicate economy, but lower civilization." 162

The greatness and durability of American civilization, commentators explained, depended upon the virtue and fitness of its working class; nothing assured that fitness better than the high wages and living standards demanded by American workers. ${ }^{163}$ "The American producer is the

160. Id. at 77 .

161. Id.

162. Id. at 74 .

163. Securing an "American standard of living," Glickman explains, became the principal goal of Gilded-Age labor agitation: "Living wages made it possible to avoid slavery and achieve republican freedom. . . . The new slavery, in this context, was a low standard of living, and the new republican freedom was the American standard of living." GLICKMAN, supra note 6, at 79. As a group of labor 
essential ingredient ... in American civilization," explained New Hampshire Republican Senator Henry Blair. He is an "American civilizer [who] has attained a position where he has a certain amount of compensation ... allotted to him in the distribution of that which he produces. ... He gets his share, and in America he gets a larger share ... " 164 Congressman Foran similarly emphasized the explicit connection between high wages and American laborers' capacity for fit citizenship. "It may be laid down as a general proposition that can not be controverted, that the rate of wages determines the social, moral, and intellectual status of a people," he explained. "Low wages mean cheap men, ignorant, degraded, dangerous citizens. . . . Cheapen labor and you destroy the incentives that spur men to effort and improvement. Low wages signify debasement, ignorance, degradation, brutality. High wages signify intelligence, ingenuity, invention, and a higher order of manhood." 165

Following this logic, the capacity of laborers to participate in the industrial economy as consumers, rather than as mere producers, became the hallmark of a distinctively American political economy and an essential ingredient in the high quality of American civilization. ${ }^{166}$ In England, editorialized the Social Economist, where the middle and upper classes had always been the "chief consumers of manufactured products," political economy had "looked to them as the main source of commercial demand. The laborers not having appeared above the social horizon, they cut no figure as the consumers of factory products, and consequently were considered only as factors of production." 167 Under such conditions "the doctrine of cheap labor received its first scientific sanction," 168 thus creating "a middle-class public policy, under whose influence the social condition of the masses was repressed rather than advanced." 169 By

leaders collectively declared in 1891, "[i]n a political sense, the high standard of living is a chief requirement for the preservation of republican institutions." THE VOICE OF LABOR: PLAIN TALK BY MEN OF INTELlECT ON LABOR'S RIGHTS, WRONGS, REMEDIES, AND PROSPECTS (H.J. Smith ed., 1891), quoted in GLICKMAN, supra note 6, at 83.

164. 16 CONG. REC. 1626 (1885).

165. 15 CONG. REC. 5351 (1884).

166. Glickman explains that during the last third of the nineteenth century the American labor movement gradually retreated from its earlier opposition to the wage system and articulated a vision of "citizenship around high wages and consumption." GLICKMAN, supra note 6, at 7. In contrast to the traditional view among workers of a just wage as the "full fruits" of one's labor, and in opposition to mainstream political economists' understanding of wage rates as the product of the natural law of supply and demand, living wage advocates maintained that "how one lived should be the criterion by which to judge the faimess of wages. Id. at 67. "Rather than as exploitation that inevitably fell short of full compensation, wages came to be defined positively in need-based language." Id. at 70 . C.f. JAMES Livingston, PRAgMatism AND the POLITICAL ECONOMY OF Cultural Revolution, 1850-1940 (1994) (describing the increasing importance in the late-nineteenth and early-twentieth centuries of consumption to American subjectivity).

167. Philosophy of Immigration and Annexation, 4 Soc. ECONOMIST 193, 195 (1893).

168. Id. at 196.

169. Id. at 196-97. 
contrast,

America represents a different type of national development and industrial civilization. ... [O]urs, from the beginning, have rested upon the life and character of the masses. . . America's . . present position at the head of civilization has been acquired, not by imitating England, but by inaugurating a new departure in national development. England's ... markets have been chiefly foreign, ours domestic. . . A American industries rest chiefly upon American consumption and American civilization. ${ }^{170}$

The greatness of American civilization was thus grounded in the distinctiveness of its political economy, the singular feature of which was the expectation that American workers' material consumption represented a meaningful source of commercial demand. Under this construction, which was indeed new in the 1880 s, the high quality of working-class consumption became both a source and symbol of relative classlessness and social mobility in the United States, and thus a constitutive element of the nation's exceptionalist identity. As historian Nancy Cohen has written, "the republic of citizen-workers was being transmuted into a public of consumers." "171

By placing a respectable working-class standard of living at the center of the revised definition of free labor, critics of foreign pauper labor helped to mollify the tense accommodation between the emergence of a permanent wage-earning class and the venerated republican ideal of virtuous citizenship. Under the Gilded-Age political economy of American citizenship, public virtue would be derived not only from independence rooted in property ownership and self-employment, but also from the receipt of a wage sufficient to afford a worker and his family a comfortable material existence and a measure of leisure. Senator Orville Platt, a Connecticut Republican, made explicit the vital nexus between the preservation of republican citizenship and the emergent definition of the "free" laborer as one who was well-compensated:

[Y]ou must add to virtue and intelligence the prosperity of the citizen, if you expect the Republic to endure .... [T] lower the

170. Id. at 197.

171. COHEN, supra note 27 , at 200. The debate over foreign pauper labor took place against the backdrop of a wholesale reconstruction of American political economy in the 1880s and 1890s. As Cohen explains, influential economists such as John Bates Clark and David Ames Wells, along with United States Commissioner of Labor Carroll Wright, advanced the "emerging idea of an 'American standard of living' that displaced traditional ideas of economic republicanism." Id at 229. Clark, who pioneered the soon-to-become dominant theory of "marginalism"-which, among other innovations, located the source of economic value in consumer demand-expressly "equated democracy with consumption," and in so doing "suggested that the test of a just society was its ability to maintain material abundance and that participation in consumer culture constituted civic participation." Id. at 213. 
standard of wages below fair remuneration is . . . vicious and destructive of republican institutions. . . Up to this time those of us who have been willing to labor in this country under our system of free labor have been able to comfortably clothe themselves and families; so that they could properly educate their children; so that by thrift and prudence ... [they] could . . . secure a little home; attach themselves to the soil, and thus become conservative, patriotic citizens of the country. ... [W]e shall but half won the fight against slave labor and in favor of free labor in this country if . . labor shall [not] be free and independent, and . . . receive fair, even generous, compensation. ${ }^{172}$

A generation earlier the idea of a republic of permanent wage earners had seemed a logical impossibility; in the 1880s, however, a broad crosssection of politicians, economists, journalists, and even many labor spokesmen could agree that generous wages and a comfortable material existence were sufficient prerequisites for fit citizenship in a thriving republic.

Critics of foreign pauper labor took special pains to shore up the fitness and virtue of "native" workers. American workers' inability, or unwillingness, to compete with the pauper laborers of Europe evidenced not their weakness as free laborers, but rather their self-respect and relative civilization. "A large majority of these immigrants," explained an Indiana Republican, "can live on what a respectable American would cast aside. . . American workmen pay the penalty for being respectable." ${ }^{173}$ It was less American workers' capacity as laborers, than their respectability and high standards of living that distinguished them favorably from their European counterparts. In the debate over foreign pauper labor, such extra-economic considerations gained an essential place alongside values such as consent and freedom in the evolving definition of free, independent labor.

The determination to preserve the "civilization" of the American wageearning class inspired unprecedented attention to immigrant laborers' living conditions. Freighted with the fate of the American standard of living, immigrants" "habits, customs, [and] modes of living" 174 became a barometer of their civilization. Both the Congressional Record and popular periodicals were replete with reports of immigrants' inability to

172. 16 CONG. REC. 1781 (1885).

173. William R. Wood, Unrestricted Immigration Dangerous to American Institutions, 2 AM. J. POL. 512, 522 (1893). Terence Powderly likewise argued that immigration was "damaging" and "unhealthy" because the wages accepted by pauper laborers obliged "native workmen" to "lower the standard of wages and living to that of the immigrant." Terence V. Powderly, Mr. Powderly on Excessive Immigration, 20 AMERICAN 76, 77 (1890).

174. 15 CONG. REC. 5349 (1884). 
appreciate the creature comforts. The consumption habits of "new" immigrants, particularly Italians and Hungarians-who in the 1880 s were just beginning to arrive in notable numbers-were often singled out for special condemnation. During floor debate, Congressman Foran highlighted the testimony of one Committee witness who had reported that Hungarian laborers "subsist[ed] upon what an American laborer could not eat-such as mules, hogs, \&c., which have been killed or died with cholera and other diseases." 175 Another witness, Foran reported, had confirmed that "Hungarians ... have been known to have taken the dead carcass of a mule, sliced it up and deal it out as rations. ... [T] he habits, morals, and modes of living of the Italians [are] of the same general character." 176 Terence Powderly, the leader of the enormously powerful Knights of Labor and the future United States Commissioner General of Immigration, corroborated such reports and urged that new immigrants' uncivilized living standards unfit them for both the American market in free labor and for American citizenship. "We have Hungarians at work," Powderly insisted, "who are no more fit to live in this country than a hog is fit to grace a parlor." 177 Powderly's choice of metaphors was not accidental. As the preeminent Victorian symbol of bourgeois respectability, the aspiration to possess a parlor represented the prospect of social mobility through material consumption. The promise of such mobility helped to reconcile the emergence in the Gilded Age of a permanent wage-earning class with the exceptionalist ideal of perpetual classlessness. Even though the typical wage laborer would never achieve old-style propertied independence and economic self-sufficiency, by obtaining a comfortable, well-appointed home cared for by a dependent wife he could nevertheless stake a legitimate claim to social respectability and virtuous citizenship.

To such critics, the prospect of a more civilized way of life appeared not even to register on the aspirational horizon of the typical foreign pauper laborer. Francis Amasa Walker described the "foreigner, making his way into the little village, bringing . . . not only a vastly lower standard of living, but too often an actual present incapacity even to understand the refinements of life and thought in the community in which he sought a home." As a result, Walker continued, "[o]ur people had to look upon houses that were mere shells for human habitations, the gate unhung, the shutters flapping or falling, green pools in the yard." 178 Not only were foreign pauper laborers willing to work for wages unbefitting a native

175. 15 CONG. REC. 5350 (1884).

176. Id. at 5350 (internal quotations omitted).

177. 15 CONG. REC. 5356 (1884).

178. Walker, supra note 158 , at $640-41$ (emphasis added). 
citizen-consumer; they were unable even to comprehend a civilized level of material consumption. ${ }^{179}$ This critique stood in marked distinction to the discourse of foreign pauperism just a decade earlier. "It is not because foreigners become paupers that their immigration should be restricted," explained the political activist Ellen Dietrick in the Social Economist, "but that they have too low a standard of social life, habits, and ideas." 180

The Supreme Court echoed this rationale when it was asked to clarify the class of immigrant laborers excluded by the Contract Labor Act. The purpose of the Act, explained a unanimous Court in the Holy Trinity Case, was to "raise the standard of foreign immigrants, and to discountenance the immigration of those who had not sufficient means in their own hands ... to pay their passage." 181 The Court continued, quoting directly from the House committee report:

This class of immigrants care[s] nothing about our institutions, and in many instances [has] never heard of them. They are men whose passage is paid by the importers. .. . [T]hey are ignorant of our social condition, and, that they may remain so, they are isolated and prevented from coming into contact with Americans. They are generally from the lowest social stratum, and live upon the coarsest food, and in hovels of a character before unknown to American workmen. They, as a rule, do not become citizens, and are certainly not a desirable acquisition to the body politic. The inevitable tendency of their presence among us is to degrade American labor, and reduce it to the level of imported pauper labor. ${ }^{182}$

In the estimation of the Supreme Court, foreign pauper laborers'

179. See 15 CONG. REC. 5361 (1884) (statement of Rep. Ferrell). Especially troubling to critics of immigrants' living standards was foreign laborers' alleged inattention to the proper gendered organization of the household-the preeminent site of consumption. Desirable immigrants, explained Congressman Cutcheon, come to the United States

with all their families, bringing their household goods and gods. They quickly learn American ways and American wages. ... [They become] consumers. They must have a cottage ... . They must have furniture . . . . They must have clothing, boots, shoes, hats, caps, and food. In short, they become embedded in the great American labor system, giving as well as taking, and investing their surplus here.

Id. at 5369 (1884). Foreign pauper laborers and the employers who import them, Foran worried, instead seemed to care little that "the family is the only true foundation upon which any government can rest." Id. at 5349. Capitalists "herd together men and women who seem to be without a clear recognition of social or moral distinctions between the sexes, if we may judge from their daily life and the manner in which they inhabit indiscriminately their large but unfurnished sleeping apartments," reported Pennsylvania Congressman William Kelley. Id. at 5354. Powderly confirmed that he had "seen nine of them, eight men and one woman, occupying two small rooms." Id. at 5357. Such disregard for the proper organization of the family economy both diminished the role of the home as unit of vigorous consumption and made a mockery of the vaunted republican ideal of the economically independent, single-male-breadwinner household.

180. Ellen Battelle Dietrick, The Restriction of Immigration, 5 SoC. ECONOMIST 21,31 (1893).

181. Holy Trinity Church v. United States, 143 U.S. 457, 464 (1892).

182. Id. (quoting 15 CONG. REC. 5359 (1884)). 
degradation of the American standard of living could poison the independence, self-respect, and political virtue of the national citizenry.

In a social and political milieu where fitness for free labor was virtually synonymous with fitness for republican citizenship, immigrants' allegedly low standard of material civilization necessarily weighed heavily against their inclusion in the political body. As Walker put it,

[to] be strong, a democratic society such as ours needs to have its members aspiring for the fullest measure of life, eager for all the advantages of contract and influence which can be achieved. . . . Where, as among peasant folk, there is no upward striving, the mass of the people is hardly profitable to the best interest of the commonwealth. ${ }^{183}$

This deep connection between the standards of laborers' material civilization, the prosperity of American citizen-consumers, and the health of the republic supplied a compelling argument for applying a more selective, and federally administered, filter to the incoming stream of immigration.

\section{The Hereditary Republic}

Critics of foreign laborers' allegedly sub-standard civilization routinely rendered their diagnoses in the increasingly resonant discourse of hereditary inferiority. They argued not merely that immigrants were disproportionately likely to be unfit as individuals-as they had in the 1870 s-but that there existed naturally defective sub-groups of immigrants, which owed their unfitness for American economic or political inclusion largely to their very racial inheritance. Some advocates of more stringent immigration restrictions explicitly denied that they were motivated by racial animus. One of the Contract Labor Bill's principle proponents in the Senate, Ohio Republican John Sherman, argued that the proposed exclusion of pauper laborers "is not on account of their race or their color, but simply because they are not in a condition to share with us in the civilization which has been founded by free men and which is to be perpetuated by the free intelligent laboring men of this' country." 184 This Section refutes that statement by revealing the subtle and not-so-subtle racial logic with which critics of foreign pauper labor pressed for new restrictive legislation. More importantly, it argues that to categorize such advocacy into "racial" appeals and "economic" appeals creates a false dichotomy. The economic arguments for tighter controls were in fact inextricable from the racial arguments, as immigrants' alleged economic

183. Id. at 650 .

184. 16 CONG. REC. 1634 (1885). 
pathology both generated and supplied the specific content of their racial assignments.

The following discussion consists of three subsections. The first demonstrates that opponents of foreign pauper labor attributed immigrants' alleged lack of affinity for material consumption - their "unAmerican" standards of domestic living - to their degraded racial natures. This logic, I argue, conflated an economic critique of labor-market degradation with a racial critique of social and political contamination. In the second subsection, I argue that the perceived menace posed by racially unfit Europeans forced on critics of liberal immigration a stark choice, between the theretofore presumed universality of their political-economic worldview and the survival of the republic. They chose survival, and in so doing decided that enjoyment of the so-called "eighteenth-century values" of universal rights, individual freedom, and political equality had necessarily become contingent on the racial natures of those claiming the privilege of economic and political inclusion. The third subsection argues that this choice both was premised on and further advanced a fundamental reevaluation of the nation's assimilationist faith, and compelled the judgment that, in order to save the nation's cherished institutions, access to those institutions would have to be restricted.

\section{Foreign Pauper Labor as Racial Invasion}

The contradictions that contemporaries observed between the ideal of free, independent labor and the ongoing crisis of dependency furnished not only the historical context, but also the specific logic of the racialization of European immigrants. The thoroughly un-American standard of living adopted by foreign pauper laborers, critics argued, was born less of low wages or poverty than of heredity, and its presence could not but poison the body politic. In his want of civilized motives, wrote Harvard scientist Nathan Shaler in The Atlantic Monthly, the European peasant immigrant "is essentially the same as the Southern Negro. . . . Centuries of experience have bred in him the understanding that he is by nature a peasant. . . . Centuries of breeding have ... checked the development of all those motives and aspirations which are the foundations of our democracy." 185 There has been "stamped in an indelible manner, the sign of inferiority on the laboring classes of the Old World." 186 The analogy between European pauper laborers and African Americans, which was

185. N.S. Shaler, European Peasants as Immigrants, 71 ATLANTIC MONTHLY 646, 649 (1893).

186. Id. at 650. See also Mayo-Smith, supra note 159, at 54, 55 ("[The] negroes of the South ... are as much an alien element in our civilization as are the foreign-born themselves. . . [Together, they equal] more than two-fifths of the entire population, who on account of race or birth or blood are in reality alien to our American population."). 
extremely common in the mid-1880s and early 1890 s, must have made unmistakably clear the racial nature of immigrants' alleged unfitness. Southern blacks-formerly as slaves and in the Gilded Age as impoverished sharecroppers and plantation hands-had long embodied hereditarily fixed, racialized, dependent labor. Critics of foreign pauper labor thus borrowed, and, in turn, reinforced, that culturally potent racial accounting of economic dependency.

Politicians and social commentators frequently heaped special opprobrium on the racial inheritance of the most recent, and increasingly visible, addition to the American laboring class-the "new" European immigrants. As Walker explained, the defective classes were "increasingly drawn from the nations of southern and eastern Europe-peoples which have got no great good for themselves out of the race wars of centuries, [and have] . . . remained hopelessly upon the lowest plane of industrial life." ${ }^{187}$ Massachusetts Republican Henry Cabot Lodge, one of the most vocal advocates of immigration restriction in the House and in the political press, was unambiguous that the invasion of foreign laborers was also an invasion of foreign races. As he proclaimed to his colleagues in 1891, "[w]e have now before us race problems which are sufficient to tax to the utmost the fortunate conditions with which nature has blessed us." 188 The changing origin of immigration was vital. "The immigration of people of those races which contributed to the settlement and development of the United States is declining," he explained, "in comparison with that of races far removed in thought and speech and blood from the men who have made this country what it is." ${ }^{\prime 189}$ Lodge included in the Congressional Record a chart detailing the changing character of immigration between 1874 and 1889; though southern and eastern Europeans still constituted only about a quarter of the European total, the demographic trajectory was unmistakable. ${ }^{190}$

187. Walker, supra note 158 , at 644 .

188. 22 CONG. REC. 2956 (1891).

189. Id. It bears mention that Lodge, like many of his restrictionist Republican colleagues, held a deserved reputation as a racial egalitarian. The previous year, he had relentlessly championed a piece of legislation-dubbed the "Lodge Force Bill" by its detractors-that represented the last realistic hope of shoring up black voting rights in the South against the wave of racial disfranchisement that swept the region after 1890 .

190. Id. Congressman Foran likewise alerted his colleagues to this demographic trend when he introduced the Contract Labor Bill. "While the immigration from Germany, Ireland, England, and Scotland, and other countries from which the best class of immigrants come, has decreased quite largely during the last year," he noted, "the immigration from Italy and Hungary has largely increased." 15 CONG. REC. 5350 (1884). Congressman Ferrell was one of many who objected explicitly to a contract labor system by which "Italians, Hungarians, Poles, Canadian French, and other inferior races are brought into competition with American citizens." Id. at 5363. See also, for example, id. at 5369 (noting that the bill is "designed . . . to exclude the degraded lazzaroni of Italy, the almost servile laborers of Hungary and other southern European countries"); id. at 5349 (referring to "the large numbers of degraded, ignorant, brutal Italians and Hungarian laborers" imported into the United 
The construction of fitness for free labor as a matter of racial character provided critics of foreign pauper labor with an important new platform from which to challenge the virtues of unbridled economic competition. Foran, the former union president, took aim at the conventional politicaleconomic wisdom "that in the struggle for existence, in the 'free for all' contest recognized by our governmental policy, the fittest and best will survive, and that the American, being better qualified for this struggle than the Italian or Slavonian, no dangers need be apprehended." 191 Those who cast their blind faith in the "survival of the fittest," Foran argued, sometimes forget that the "fitness" to which that law of nature refers "is not necessarily what from moral, intellectual, or esthetic considerations would be called the superior." 192 The crisis in foreign pauper labor thus complicated the Social Darwinist arguments that classical liberals had adopted to condemn dependency as pauperism and to defend an unregulated market in wage labor. ${ }^{193}$ In the 1870 s, mere survival without the assistance of charity testified to a minimal level of fitness. During the crisis of foreign pauper labor, by contrast, unassisted survival by itself proved nothing about the quality of the prospective citizen-worker; civilization was now measured by an altogether different metric.

Through images of national invasion and infestation, commentators described a civilized yet highly vulnerable American citizenry. Congressman Cutcheon's torrent of metaphors is representative. Foreign pauper laborers, he declared, were

the Goths and Vandals of the modern era. They come only to lay waste, to degrade, and to destroy. They bring with them ignorance, degraded morals, a low standard of civilization, and no motive to intended citizenship. Like the vast flights of grasshoppers and locusts that a few years since devastated our Western prairie states, they

States like "so many cattle"); and $i d$. at 5354 (counseling that the United States resist "welcoming to the ranks of our laborers men and women from the worst associations of Eastern and Southern Europe"). Such statements notwithstanding, the Irish also remained variably subject to unfavorable racial construction even decades after they presumably had been culturally "whitened." See NOEL IGNATIEV, HOW THE IRISH BECAME WhITE (1995). For Gilded-Age racializations of the Irish, see W.M.F. Round, Immigration and Crime, 8 Forum 428, 430 (1889) ("It takes more than one generation to get the taint of "effete monarchy' out of the blood"; "the shamrock is a plant of . . strong root ...."). See also supra text accompanying notes 105-107 (discussing the alleged hereditary deficiency of English "tramps" during the 1870s crisis of dependency); infra text accompanying note 213 (discussing the incompatibility of the German and Canadian races with the American Constitution). The persistence, or perhaps renewal, of Irish racial difference underscores that GildedAge racialism was a response more to the crises of mass dependency than a simple reaction to the distinct geographic origins, customs, and languages-the percejved "foreignness"- of the most recent arrivals.

191. 15 CONG. REC. 5351 (1884).

192. Id.

193. The most prominent example of the theme of social Darwinism in Gilded-Age classical liberal thought is William Graham Sumner, What the Social Classes OWe to Each Other (1883). 
sweep down upon our fields of labor to devour and strip from us the benefit of our customs and the laws protecting American labor, and then take their flight again back to the breeding places from which they came. ${ }^{194}$

Such overwrought language imagines a citizenry in perpetual jeopardy of violation. As Republican Senator Lot Morrill remarked, the nation was being overrun by immigrants "more dangerous to the individuality and deep-seated stamina of the American people, and more worthy of rigid quarantine, than even the most leprous diseases." Morrill was referring specifically "to those whose inherent deficiencies and inequities are thoroughbred, and who are incapable of evolution, whether in this generation or the next, as is the leopard to change his spots." 195 The Senator's remarks illustrate the emerging construction of European immigrants as a foreign plague infesting the American labor market. This was a hereditary inheritance that, unlike the pauperism of the previous decade, could not be unlearned, rehabilitated, or "sweated out" of its carriers, and whose generational transmission could not be halted. If immigration were left unchecked, editorialized the charity periodical Our Day in 1889, the nation would be offering itself up as "the natural cesspool for the reception of the human offal and rubbish of the entire world." 196 European immigration had threatened to become, as Walker warned, "not a re-enforcement of our population, . . . but a replacement of native by foreign stock." 197

\section{Revisiting Universal Principles: Citizenship and Racial Difference}

Critics maintained that because racially unfit laborers degraded not only America's labor market and racial stock, but also the quality of its citizenship, unchecked immigration placed in jeopardy the very political foundation of the republic. In an 1891 issue of the North American Review, Congressman Lodge again intoned that "the immigration of people removed from us in race and blood is rapidly increasing," and urged that whatever economic benefits might accrue from such additions would be "dearly bought if we pay for them a price which involves the lowering of the standard of American citizenship."198 As Lodge's formulation underscores, the nation appeared to be crossing a great bridge between national historical epochs. It was leaving behind forever the

194. 15 CONG. REC. 5369 (1884).

195. Senator Morrill, quoted in Round, supra note 190, at 428.

196. New Reasons for Restricting Immigration, 3 OUR DAY 127, 131 (1889).

197. Walker, supra note 158, at 624. See also Powderly, supra note 173, at 77.

198. Henry Cabot Lodge, Lynch Law and Unrestricted Immigration, 152 N. AM. Rev. 602, 611 (1891). 
Jeffersonian and Lincolnian republic in which property ownership and independent labor were the wellsprings of virtuous citizenship, and entering into a new, distinctly modern era. The nation's traditional "liberality toward immigration, combined with the normal growth of the population in the course of the present century," wrote Lodge, "rapidly filled the country, and the conditions under which at the outset we had opened our doors and asked every one to come in changed radically."199 Specifically, the United States "no longer [has] endless tracts of fertile land crying for settlement. ... [T] he conditions have changed utterly from the days when the supply of vacant land was indefinite, the demand for labor almost unbounded, and the supply of people very limited." 200 The traditional ingredients of the exceptional republic, in other words, had ceased to exist. Unless aggressive action were taken, the United States surely would be shaken by the same social crises that afflicted Europemass poverty, class conflict, radicalism, and political instability. Indeed, according to Lodge, that time had already arrived. "In many parts of the country," he wrote, "the struggle for existence in large cities has become as fierce as in the Old World. ... This tendency is perilous both socially and politically." 201

The problem of foreign pauper labor thus presented an unsettling contradiction: On the one hand, American citizenship and political institutions were purportedly rooted in universally applicable Enlightenment principles, such as political freedom, equality, and the natural rights of man. As the periodical Our Day explained in 1889,

The constitution of the United States breaths a sanguine spirit. It is founded upon trust in human nature. ... When the founders of the American Republic stretched out their hands with a hospitable welcome to all the oppressed of the earth, it was in large measure because Rousseau had them taught to believe in the inherent goodness of man. They took for granted that the oppressed, no matter who they were and whence them come, were deserving characters, who needed only the liberty which the new republic offered them, to grow to the full stature of civic, moral, and intellectual manhood. ${ }^{202}$

The historically successful assimilation of European immigrants to republican institutions appeared to confirm that universality. ${ }^{203}$ On the

199. 22 CONG. REC. 2957 (1891).

200. Id.

201. Id.

202. New Reasons, supra note 196, at 126-27.

203. This assertion is complicated by the uneven but persistent fact of racial discrimination against blacks in the postbellum South, and by the rise of Jim Crow laws concurrent to the racialization of European immigrants. It is worth noting, however, that the northern Republican logic of racial difference and citizenship with respect to southern blacks in the period between the end of the 
other hand, Our Day editorialized, "[t]he eighteenth century knew little of the influence of heredity." 204 The specter of unfit foreigners degrading the quality of the American citizenry, and thus American citizenship itself, now counseled against their indiscriminate inclusion within the national political body. ${ }^{205}$

In the end, most critics of foreign pauper labor concluded that liberal constitutional principles such as political freedom and equality were not, after all, generally applicable, but rather were implicitly premised on each would-be citizen's possession of a suitable racial inheritance. A remarkable variety of observers considered the old presumption that all comers were suitable to liberal political institutions to be a dangerous anachronism. As Our Day put it, the nation was experiencing an influx of foreigners

not dreamed of by the founders of the republic; and if it had been dreamed of, some effective safeguard would have been devised to protect their cherished institutions from the dangers to which they would inevitably be exposed in the hands of a semi-alien race, in conflict with an alien spirit. ${ }^{206}$

Commentators routinely asserted that the capacity for self-government and for participation in republican political institutions was a racially specific intellectual trait. The theory of Anglo-Saxon constitutionalism expressed in the Our Day editorial was typical:

The constitution ... was framed by men of Anglo-Saxon origin for their own government; and it presupposes the long political evolution to which that race has been subjected in the mother-land during eight or nine centuries. It presupposes Anglo-Saxon virtues of moderation, self-restraint, and sense of fair play. It is only a high civilization which exhibits these virtues; and to impose free institutions upon a people which does not possess them, is to endanger the social order and bring free institutions into unmerited reproach. ... It takes generations of intelligent, self-restrained, and self-respecting

Civil War and the 1890s shared more with that of European immigrants than one might at first imagine. See Heather Cox Richardson, The DEATH of Reconstruction: RaCe, Labor and POLITICS IN THE POST-CIVIL WAR NORTH, 1865-1901 (2001).

204. Id.

205. The political scientist John Hawks Noble acknowledged this tension explicitly. Rather than "making race a test of fitness"- the policy that the United States had "adopted with reference to the Chinese"- he advocated the imposition of a literacy test on would-be European immigrants because "it makes the least inroad on the doctrine that every individual is a free citizen of the world, - - an abstract theory for whose sake we are sacrificing the great advantage of our elbow-room and risking our national character, with a generosity at which foreign critics have long wondered." John Hawks Noble, The Present State of the Immigration Question, 7 PoL. SCl. Q. 232, 243 (1892).

206. New Reasons, supra note 196, at 128. 
ancestors to make a man fit to govern himself. . . . ${ }^{207}$

The principle of universal political freedom and equality, of which the United States Constitution was the most concrete expression, had been premised on the now-doubtful truth that all men were indeed created equal. As the editorial explained, "[a] republic can only be carried on by republicans." 208 A "republican" would no longer be defined by the fading antebellum virtues of personal independence, or social mobility, or simply participation in republican institutions. In the racialist logic of the new era, republicans were born, rather than made. In light of modern knowledge of human nature and racial difference, the applicability of the Constitution had to be understood not as universal, but rather as contingent on the racial character of those claiming access to the American polity. ${ }^{209}$

As the nation's lawmakers debated the crisis of foreign pauper labor, they, too, found cause to question whether it was appropriate to extend indiscriminately the nation's traditional liberality to its newest candidates for economic and political admission. Kansas Senator John Ingalls, a radical Republican and vocal defender of black suffrage, urged his colleagues "to consider whether the doctrines of the natural rights of man as applied to this continent have not reached a dangerous extremity, [and] .. . whether every man, woman, and child on the face of this earth, no matter what may be his physical, mental, or moral condition, has the natural right to come to this country ... to the detriment . . . of those already here. ${ }^{, 210}$ In order to reinvigorate the self-evident, universal truths and political principles upon which the republic was founded, Ingalls suggested, their significance would have to be modified. Elaborating a line of reasoning that would have seemed paradoxical just a decade earlier, the sponsors of the Contract Labor Bill argued that in order to "leave[] all natural laws, business laws, social laws, industrial laws to their natural

207. Id. at 128-29. Mayo-Smith similarly cautioned that " $[\mathrm{t}]$ he thing we have to fear most is the political danger of the infusion of so much alien blood into our social body that we shall lose the capacity and power of self-government." Richmond Mayo-Smith, Control of Immigration, 3 POL. SCI. Q. 409,415 (1888). See also Wood, supra note 173, at 521.

208. New Reasons, supra note 196, at 129.

209. Perhaps no one person melded a commitment to the universalistic ethos of liberal republicanism with virulent racialist nativism as prominently as Reverend Josiah Strong, a founder of the Social Gospel Movement and a powerful critic of the mass poverty born of unrestrained industrial competition. Strong's 1885 book Our Country was one of the era's most influential tracks on AngloSaxon Protestant supremacy and the importance of restricting entry into the United States of inferior European races, even as it brimmed with liberal optimism, praise for popular sovereignty, and calls for government action to redress economic inequality. See SMITH, supra note 20, at 353-56.

210. 16 CONG. REC. 1624 (1885). "Although I recognize in a broad sense the brotherhood of man and our obligations to all men," Congressman Cutcheon declared, "the Almighty has made us Americans. ... Our first duty is to America and to Americans; to build here a great, free, enlightened and fruitful civilization ... that shall hold as precious above all things the manhood of the individual man." 15 CONG. REC. 5370 (1884). 
effect and operation," 211 Congress would have to intervene in the labor market to deny access to the unfit. The Bill would thus preserve the natural operation of liberal economic laws by limiting their applicability to those whose natures were suited to American civilization and citizenship.

As the forgoing discussion suggests, the campaign to exclude foreign pauper laborers represented far more than an effort to check the entry of those whose passage to the United States had been assisted. Rather, it was a movement to filter out members of the inferior national races without checking the entry of the superior ones. "To the warm-hearted and intelligent Celt, to the industrious and economical German, to the selfreliant Scandinavian, let the doors of the Republic be thrown wide open," ${ }^{212}$ trumpeted Missouri Senator George Vest. The new legislative challenge, explained a critic in the popular Chautauquan, was to encourage the immigration of those nationalities who had long furnished the United States with "noble patriots," while restricting the entry of those from the "south and eastern part of Europe which have not held their own in the race struggle," and who were "least capable of understanding our institutions, or adapted to responding to the opportunities and privileges of a free government."213 The prohibition against pauper labor would defuse the national crises of dependency by excluding those whose racial endowments presumably disabled them from harmonizing liberal economic freedom and virtuous republican citizenship.

\section{Unassimilability}

Throughout the nation's history, the speedy cultural and political assimilation of new additions to the citizenry had been a cardinal premise of the regime of free immigration. During the debates over the Contract Labor Bill, Congressman Maybury reflected on the importance of assimilation to the health of the republic:

In the century of our existence as a nation no feature of her history is more plainly marked than that which records the ready assimilation

211. 16 CONG. REC. 1624 (1885) (statement of Sen. Blair).

212. 16 CONG. REC. 2780 (1885).

213. Canby, supra note 158, at 199. See also Arthur Cassot, Should We Restrict Immigration?, 3 AM. J. PoL. 244, 249-50 (1893). Yet even the very same nationalities that that were frequently celebrated as the ideal raw material for economic and political independence sometimes came under attack. Addressing the "influx of elements . . alien to the old New England character," Mayo-Smith declared, "[i]t is scarcely possible to conceive of the Fathers adopting the mass of Catholic Irish and French Canadians and beer-drinking Germans who make up the foreign-born." Mayo-Smith, supra note 159, at 57. The Irish were frequently the object of particular opprobrium. See A. Cleveland Coxe, Government by Aliens, 7 FORUM 597, 600-01 (1889). Such statements suggest that the surge of racialist nativism between the mid-1880s and early 1890 s was less a response to the perceived heightened "foreignness" of new immigrants' language and culture than a means of adapting liberal republican values to the exigencies of the new era. 
on the part of the masses of honest emigrants with those of this land and to the manner born. Had not the friendship for the institutions of this land, respect for her laws, and loyalty to her interests marked the emigrating millions, how unstable the framework of popular government would be. ${ }^{214}$

In the context of the crisis of foreign pauper labor, however, immigrants' desire, and even capacity, to assimilate fell into doubt.

Popular political and social scientific periodicals between the mid-1880s and early 1890 s are filled with admonishments to readers that, without the requisite economic conditions and racial material, the promise of citizenship was by itself of little value as a force of assimilation. One author presented the problem to the readers of The Chautauquan with an especially illustrative image: "The popular orator is the one who pictures our governmental domain as a huge hopper into which the grist of any and every nation may be poured, to come out liberty-loving, law-abiding Americans, through some mysterious civic alchemy of whose transforming powers we are superstitiously credulous." But the appearance of "foreign colonies in our large cities," the article continued, whose inhabitants were "making no effort to become American warns that the hopper is either choked from overfilling or that it is not doing its proper work." ${ }^{215}$ At the heart of this pessimism lay a deep concern that the industrial transformation of labor-the historic displacement of the independent, agrarian producer by the industrial hireling--had rendered anachronistic the republican ideal of virtuous, independent citizenship. The belief that "the earth is the great disinfectant," cautioned Mayo-Smith, "and that all we need to do is get these depraved dregs of European civilization on to the land in order to reform them,-it is in early civilization that this saying is true." 216 "As long as there was no danger of the labor market becoming overstocked," agreed Roosevelt in 1888, "we were able with safety to trust to our extraordinary powers of assimilation to turn immigrants or their children sooner or later into American citizens, with the same feelings, prejudices and habits of thought as the rest of us." 117 "The growth of a proletariat," however, "would surely in the end

214. 15 CONG. REC. 5353 (1884).

215. Canby, supra note 158 , at 199.

216. Mayo-Smith, supra note 207, at 413. Elsewhere, Mayo-Smith cautioned against any "pleasant optimism about this conception that the child born on this soil and breathing this air becomes a full-born American. . . . But there is still the foreign blood," he warned, "and in a good many cases the foreign language and customs." Mayo-Smith, supra note 159, at 54.

217. Roosevelt, supra note 151, at 85-86. See also Mayo-Smith, supra note 159, at 53. In the first part of the century, Mayo-Smith argued, "the foreign increment . . . could be readily and rapidly assimilated; it did not add itself to an unassimilated mass already present. . . . There came, in those early days, no great mass of unskilled labor, crowding the unskilled occupations. . . Even in the period from 1865 to 1873 the very activity of speculation and railroad enterprise made an opening for 
bring the overthrow of the whole system.." ${ }^{218}$ As critics of foreign pauper labor meditated on the problem, their former confidence that immigrants would be economically, culturally, and politically "Americanized" largely vanished. ${ }^{219}$

The debate over the efficacy of America's assimilationist "hopper" mapped directly onto the division of opinion over whether the exceptionalist ideal of a classless society of free, independent laborers remained viable. To a significant extent, opinion divided along regional lines. Speaking for the North (and to a lesser extent, the Midwest), Pennsylvania Republican William Kelley cautioned that opponents of the Contract Labor Bill could no longer indulge the conceit that the United States was immune from the devastating economic conditions that afflicted European laborers. "I have looked upon the misery of the British, French, Belgian, German, and Austrian laborers," he announced, and "I painfully admit that specimens of [such ills] all can be found in this country. . . . They are merely seminal here; . . . but you will find them blooming everywhere you find population all condensed." 220 On behalf of the South and West, Texas Senator Richard Coke retorted that the Bill's proponents appeared concerned only with the "Northern and Eastern States, which are said to be overstocked with labor," while ignoring the "great scarcity of labor" in the rest of the country. "We in the South and West want labor; we need men, women, and children to labor in our fields ... to grow up and constitute a part of the landholding citizenship of the country ..."."221 In controversion of the myopic pessimism voiced by critics in the industrial sections of the country, a vocal southern congressional contingent argued that if modern conditions of wage labor were a source of degradation and dependency in the North and East, the remedy was not to check immigration, but rather to channel foreign laborers to those regions where they were needed. The United States had not yet reached the end of its exceptional history, southerners argued; the

the new-comers." Id. at 53. "We are no longer in that vigorous early civilization when we could digest almost anything sent to us and when the very conditions of life here corrected and controlled the weaknesses of the immigrants." Id. at 68.

218. Roosevelt, supra note 151 , at 88 .

219. Contemporaries' faith in the assimilative power of the United States hinged on their confidence in the nation's ability to preserve, or restore, free and independent labor as the economic paradigm. Even dissenters from the prevailing anti-immigrant sentiment confirmed the close relation between the health of the free labor system, and the fitness of the immigrants who participated in it. The political economist Edward Atkinson, for example, pinned his continuing confidence in assimilation on the availability of land and the decentralization of industrial production. "Great forces are now in action," he assured the readers of The Forum, "tending to break up the concentration of the factory system, which will also very surely break up the congestion in cities by diffusing the working population throughout the suburbs and over wider and wider areas." Edward Atkinson, Incalculable Room for Immigrants, 13 FORUM 360, 370 (1893).

220. 15 CONG. REC. 5354 (1884).

221. 16 CONG. REC. 1788 (1885). 
means for achieving economic independence and republican citizenship remained available for all who would grasp them. "An immigrant can not land upon [Texas] soil and breath that atmosphere without feeling that he is a free man," Coke continued. "The servile labor Senators speak of in the North and East does not and can not exist there. Homesteads are too easily acquired for that. . . The man with labor in his muscles is more independent than in any other country under the sun."222

Yet to advocates of stronger control over immigration, it was becoming clear that the universalist economic and political principles according to which European immigration had been governed-or, more precisely, left ungoverned-in the past had actually always rested on an increasingly visible substructure of historical contingencies. "As long as Uncle Sam has a farm for every man," Roosevelt explained, "just so long he will gladly welcome every honest immigrant, whatever his creed or his language; but the minute the supply of farms threatens to give out, then to admit shoals of hungry expectants would be of no benefit to them, and would be a great detriment to the people already in the land." 223 Only if Congress were to impose a "gradual check" on immigration, "so as to keep out the least desirable kinds of immigrants, and to lessen the bulk of the immigration," would the nation be justified in trusting its "assimilative powers, firm in the belief that in a generation or so the new comers will be changed into Americans, with enough morality and intellect to . . become small capitalists on their own account." 224 To retain the nation's longstanding practice of liberally admitting European immigrants at a time when most wage laborers would never become "small capitalists" would destroy the quality of American citizenship. Yet in spite of their apparently keen awareness that the source of the newly conspicuous contingencies was the industrial reorganization of labor, critics like Smith and, to a lesser extent, Roosevelt indicted not the wage system itself, but the allegedly degraded character of those who inhabited its lowest levels.

As the foregoing discussion suggests, critics of foreign pauper labor described a national landscape in which a racialized foreign menace posed a threat of invasion-at once economic, cultural, political, and racial-to an entity called the "American citizenry." I have thus far treated that concept as though it bore a self-evident meaning that pre-existed the debate over foreign labor. That was not the case. The story of how GildedAge political and intellectual elites made sense of the crises of American dependency is also the story of how a distinctively modern conception of the American citizenry came into being. It is to this new understanding

222. Id.

223. Roosevelt, supra note 151 , at 89 .

224. Id. at 88. 
that I now turn.

\section{Federal Policing of the New American Citizenry}

In a different ideological context, policymakers and others might have recognized in the Gilded-Age crises of dependency the consequences of the industrial reorganization of the economy, including mass urbanization and the deskilling of labor. Such an interpretation could have suggested remedies such as accommodating organized workers' demands for a legislatively mandated living wage and shortened workday, or strengthening the bargaining position of unions to countervail the economic power of large employers. That is, critics of dependency could have advocated regulatory interventions that focused on the structure of, or balance of power within, the labor market. ${ }^{225}$ Yet with the notable exception of labor spokesmen, they generally eschewed such options, and instead located the peril of "pauperizing" labor in the racial differences borne by a distinctly foreign agent-the dependent laborers themselves. This discourse of national self-defense against an external menace counseled not reform of the rules governing participation in the labor market, but rather the restriction of access to that market through the exclusion of the unfit.

Through their construction of this new menace, Americans were engaged in a subtle, and probably little-noticed, transformation of how they understood and talked about their political body. For most of the nation's history, its exceptionalist identity had resided in the extraordinary economic and political equality enjoyed by its white, male, propertied citizens, presumably secured for all time by its vast, open frontier and robust constitutional democracy. The American polity, under this view, was subject to a process of perpetual regeneration; its progressive nature ensured by the republic's unique economic resources and political machinery. As the crisis of foreign pauper labor threatened contemporaries' exceptionalist faith-as they began to doubt the selfsustaining quality of the American economic and political system-they reconceived the nature of the citizenry itself. As the contours of their reconstructed vision took shape, the American polity looked less like the assimilationist "hopper" of old than a kind of vast national reservoir of human material, consisting of the aggregate heredity of all those whose natural endowments had been permitted to flow in.

This transformation amounted to nothing less than the birth of a new, distinctively modern understanding of the American polity. The relative quality of the citizenry would no longer depend predominantly on new 
arrivals' exposure to the uplifting influences of free labor and republican political institutions. Rather, it would be defined explicitly in opposition to that which threatened to degrade it-the uncivilized, racially inferior, citizenship-decaying material of unfit immigrant laborers-and its quality preserved only by excluding such material. Significantly, the expositors of the new American citizenry made routine use of corporeal metaphors. Unless immigration was checked, warned Roosevelt in 1888, "the whole national body [will] deteriorate."226 Ohio Republican Benjamin Butterworth similarly admonished his colleagues that unchecked immigration constituted "a kind of moral disease which is vastly more injurious to the country than to have it flooded with small pocks." 227 Such images represent more than rhetorical color. They signal an emergent conception of the citizenry as a kind of unified entity or organism composed of constituent elements whose condition could, through proper monitoring, be definitively known and, if need be, excluded. As Shaler put it in The Atlantic Monthly, eligibility for national inclusion should turn on the "extent to which the foreign people we receive are already fit . . . for incorporation into the body of American citizens."228

By conscientiously filtering the material that would nourish the national body, the government could go a long way toward insuring the nation's good health. This vision formed the conceptual groundwork of the functional equivalent of a new federal police power. Because judgments about immigrants' fitness would shape the national character, the responsibility could not properly rest with individual states. The duty of self-preservation, the role of, as Lodge put it, "sift[ing] the chaff from the wheat," 229 fell squarely on the federal government. Immigration regulation had become a variety of public health policing, but on a necessarily national scale. At issue was no longer merely weeding out the insane, diseased, or dependent - the kind of public health, morals, or welfare regulation traditionally addressed through the police powers of individual

226. Roosevelt, supra note 151 , at 88 .

227. 22 CONG. REC. 3177 (1891).

228. Shaler, supra note 185 , at 648 . Both sides of the immigration debate anthropomorphized the national body in remarkably similar terms. Speaking against the Contract Labor Bill, Senator Thomas Bayard, a Delaware Democrat and future Secretary of State assured his colleagues that because "[s]elf preservation" was "the first instinct of nature, the instinct of society as organized and of the individuals that compose it, ... the manhood of American citizenship [would] properly assert itself" without the proposed legislation. 16 CONG. REC. 1625 (1885). Even this opponent of enhanced restrictions thus conceived of the national political self as possessing a kind of human nature, both analogous to and culled from the natures of its constituent members. Supporters of the proposed legislation countered that the bill expressed, rather than preempted, this impulse. As Roosevelt counseled, the nation's "first duty" was "the duty of self-preservation." Roosevelt, supra note 151, at 89.

229. 22 CONG. REC. 2956 (1891). 
states. The world described by the Supreme Court in New York v. Miln ${ }^{230}$ half a century earlier - where state officials policed foreign paupers under the very same authority they used to police home-grown criminals-had become virtually unrecognizable. The meaning of pauperism-economic, political, and racial-had now overflowed the bounds of locality and hence transcended the jurisdictions of individual states. In the post-1884 era of foreign pauper labor, not only the defense of the nation against racially degraded workers was at stake, but also the fitness of the American citizenry, the quality of citizenship itself, and, ultimately, the very health of the republic. As Noble put it, "self-preservation requires the United States to restrain the foreign tide that is flooding in."231 "Anybody who isn't fit to become a citizen . . . isn't fit to come here at all," intoned another author in The Social Economist. "We don't want him, and he should be debarred because he is bad. Draw the lines of entrance tight and taut ...."232

The "bad" could only be debarred through a rigorously administered governmental intervention into a process that in earlier times had been left to the "natural" laws of human behavior and economic competition, and tempered only by the gentle hand of the New York Commissioners. In an era when pauper laborers imported under slave-like conditions threatened to degrade American civilization, Mayo-Smith explained, the federal government was "obliged to interfere in the process of natural selection in order to make sure that only the fittest survive."233

While proposals to reform federal immigration law were numerous and varied, all shared the unambiguous purpose of preserving the racial integrity of the national body. One of the most popular would have required would-be immigrants to obtain a "certificate of character" from an American consul before they would be permitted to board a ship bound for the United States. ${ }^{234}$ The Nation advocated a similar system of inspection, under which the American consul in each immigrant's country of origin would issue a certificate of fitness for immigration to the United States "only when [he] is reasonably sure that the applicant is capable of self-support and intends to support himself and his family." 235 Lodge championed a requirement that immigrants pass a literacy test, either in

230. See supra text accompanying notes 64-67.

231. Noble, supra note 205, at 238.

232. Samuel Epes Turner, The Immigration Problem, 2 Soc. ECONOMIST 358, 365 (1892).

233. Mayo-Smith, supra note 207, at 416.

234. 22 CONG. REC. 2946 (1891) (statement of Rep. William Oates).

235. Immigration Again, supra note 139, at 108. Others approved of the principle of "sifting" immigrants before they left Europe, but argued that the steamship companies were better suited than the consuls to "secure the regulation of the immigration and its inspection at its fountain head." Gustav H. Schwab, A Practical Remedy for the Evils of Immigration, 14 FoRuM 805, 812 (1893). 
English or in their native language, as the only way to achieve an "intelligent restriction or sifting of the total mass of immigration." Such a test, he explained, "would sift the immigrants who come to this country, and would shut out in a very large measure those elements which tend to lower the quality of the citizenship." ${ }^{236}$ Francis Amasa Walker advocated requiring a sizeable "deposit" from each immigrant, both as an indemnity against the cost of his future support and as proof of his economic fitness. As one author explained, such a measure would "reclaim our country from the unenviable distinction of being the 'dumping ground' for the earth's refuse. It would not meanwhile debar thrifty Anglo-Saxons, Teutons, or Celts." 237 Finally, a vocal minority urged making "race" the explicit test of eligibility, essentially presaging by three decades the thrust of the 1924 Act. ${ }^{238}$ Although the presumed congressional authority to enact each of these proposals lay in the Commerce Clause, such pervasive attention to the nation's intermeshed racial, economic, and political health suggests that advocates viewed each such reform as something closer in purpose to a federal police measure.

Despite spirited lobbying by those inside of Congress and out, the Immigration Act of 1891 adopted none of these proposals. The Act ultimately reaffirmed the key elements of the 1882 Act and the Contract Labor Act of 1885, with three significant additions. First, it reincorporated and broadened the police purposes of the earlier laws, adding to the excludable classes "persons likely to become a public charge, persons suffering from a loathsome or a dangerous contagious disease," "polygamists," and "any person whose ticket or passage is paid for with the money of another or who is assisted by others to come." 239 Second, it prohibited steamship companies and American employers from "encouraging" immigration through printed advertisements, solicitation by agents, or otherwise. ${ }^{240}$ Most importantly, however, the 1891 Act

236. 22 Cong. ReC. 2958 (1891). See also John B. Weber \& Charles Steward Smith, Our National Dumping Ground: A Study of Immigration, 154 N. AM. REv. 424, 438 (1892) (advocating a "reading and writing qualification" to "improve the[] quality" of "the enormous human stream"). "The test of illiteracy," wrote Noble, is "politically a fair test of intelligence, and socially a fair test of the standard of living. ... It has been estimated that the actual effect of the test ... would be to exclude seventy-five percent of the Poles, Italians and Hungarians, three percent of the Irish, two percent of the English and one-tenth of one percent of the Germans ...." Noble, supra note 205, at 242.

237. Canby, supra note 158, at 200. See also Philosophy of Immigration and Annexation, supra note 167, at 199 (To require proof of substantial cash savings as a condition of landing would "furnish an economic process of natural selection.").

238. See, e.g., Noble, supra note 205, at 242 ("A race test restriction drawn so as to correct the ethnic changes in the new immigration would have a good effect."). On the racial dimension of the Immigration Act of 1924, see Ngai, supra note 18.

239. Act of 1891, supra note 5, §1. Section 11 of the Act provided that "any alien who becomes a public charge within one year after his arrival in the United States from causes existing prior to his landing therein shall be deemed to have come in violation of law and shall be returned." Id. $\$ 11$.

240. Id. $\S \S 3,4$. Section 3 made it a violation of the Act to "assist or encourage the importation or 
transferred the sole authority to administer immigration regulationsincluding the inspection of newly landed immigrants, the decision to return undesirables, the promulgation of administrative rules, the adjudication of alleged violations, and the assignment of penalties- to the federal government, creating the office of the Superintendent of Immigration under the authority of the Secretary of the Treasury. ${ }^{241}$ The federalization of immigration regulation was complete.

As I have argued, that process was shaped by the desire of Gilded-Age legislators and other critics of dependency to preserve the vaunted ideal of a republic of free, economically independent, politically virtuous citizens, in the face of an industrial transformation that rendered the material and ideological underpinnings of that ideal anachronistic. The federal assumption of control over immigration was grounded in a vision of the American citizenry in which its constituent members' racial endowments, rather than their relationship to property or labor, would sustain the exceptionalism of the republic.

\section{CONCLUSION}

Postbellum political economy was rooted in ostensibly universal Enlightenment values-the voluntariness of individual consent, the entitlement of citizens to political freedom and equality, and the natural rights of man. In theory, such principles were diametrically opposed to the ascriptive inegalitarianism that underlay the Gilded-Age federalization of immigration law. For this reason, it is logical to conclude, as some scholars have, ${ }^{242}$ that racialist nativism triumphed politically and legally in spite of the nation's universalist commitments. The analysis presented here supports a very different conclusion: that contemporaries seized on the discourse of racialist nativism when they did precisely because it enabled them to reconcile their liberal republican values with an industrial labor system that seemed to place the continuing coherence of that worldview into jeopardy. Far from providing an antidote, or counterweight, to the surge of racialism, Americans' liberal republican commitments literally led them to, and were vindicated by, their embrace of racialism.

This Article further shows how economic and racial meanings were

migration of any alien by promise of employment through advertisements printed and published in any foreign country, and any alien coming to this country in consequence of such an advertisement shall be treated as coming under a contract." Id. §3. Section 4 provided that "no steamship or transportation company or owners of vessels shall directly, or through agents, either by writing, printing, or oral representations, solicit, invite, or encourage the immigration of any alien into the United States." Id. $\$ 4$.

241. Id. $\$ 7$.

242. See supra notes 20-22 and accompanying text. 
mutually instantiated. I have sought to move beyond the contention that immigrants were made "scapegoats" for the nation's deeper economic problems, or that their alleged economic pathologies were "racialized"both accurate, though somewhat unremarkable, conclusions. Instead, my analysis illuminates how the fact of that racialization, as well its particular content, are unintelligible apart from the ideological exigencies of the moment. The Article thus provides insight into both the stubborn durability and extreme protean quality of ideas about racial difference. Only once we understand the discursive interdependence of economic and racial categories can we begin to grasp how and why the meaning of "race" changed so dramatically in just two decades-how it was that in 1870 European immigrants could represent the vigorous raw material of a prosperous republic; in 1880 the degraded, yet potentially redeemable, carriers of hereditary economic dependency; and in 1890 the uncivilized and racially degenerate assailants of the American nation. In each of the two latter cases, contemporaries rationalized an unexceptional picture of the industrial United States by attributing the perceived pathology of the moment to the degraded, yet variable, racial natures of European immigrants.

Through this series of interpretive and diagnostic choices, northern policymakers, political intellectuals, social reformers, political economists, judges, labor leaders and others transformed both the prevailing purpose of immigration regulation-from policing the environment into which immigrants landed, to policing the fitness of the immigrants themselves-and its institutional locus-from the states to the federal government. In the process, they supplanted Americans' traditional faith in the social and political virtues associated with independent producerhood with a new emphasis on hereditary fitness, and helped to usher in a genuinely novel and distinctly modern American exceptionalism for the industrial era. 
